\title{
The Establishment Clause, Civil Religion, and the Public Church
}

\author{
Michael M. Maddigan $\dagger$
}

The Supreme Court's Establishment Clause cases over the last fifty years have yielded a set of sometimes-inconsistent decisions. The author suggests that the Supreme Court's inability to address this issue concretely stems from the Court's disregard of religion's sociological function in American culture. He argues that the drafters of the Constitution understood religion's unique function in American society and that this function has not fundamentally changed in the past 200 years. Building on these conclusions, the author presents two sociological insights. The first is a Toquevillian three-sector model of American society consisting of the state, the market, and civil society. Since the survival of civil society, the author argues, is constantly threatened by the expansion of the other two sectors, one goal of First Amendment interpretation should be to preserve the integrity of civil society. The second is the existence of an American civil religion that forms an integral part of civil society. Although civil religion may be characterized by values that overlap with those of traditional theistic religions, the author concludes that civil religion embodies values that are essential to American democracy. Government advancement of civil religion, therefore, should not be subject to Establishment Clause scrutiny at all. The author then identifies the characteristics of civil religion and shows how government advancement of civil religion can be distinguished from the advancement of theological religion that should trigger Establishment Clause scrutiny.

$\dagger$ Law Clerk, Honorable William D. Keller, United States District Court for the Central District of California. B.S.F.S. 1989, Georgetown University; J.D. 1992, Boalt Hall School of Law, University of California, Berkeley. I would like to thank Professors Jesse Choper of Boalt Hall and Joln A. Coleman, S.J., of the Jesuit School of Theology in Berkeley for encouraging and guiding my thought in this area. I also thank my father, William Maddigan, and my grandmother, Evelyn Maddigan, for all their support during law schiool; Joseph DeMarco for helpful comments on earlier drafts; Robert Holland, without whose excellent editnig the argunients made here would liave been far less clear; and especially my wife Debbie for all of her support and love. I dedicate this Comment to the memory of Andrew Michael Blatter (April 13, 1977 - October 27, 1991), friend and brother:

[W]lhen he shall die,

Take him and cut lim out in little stars,

And lie will make the face of lieaven so fine,

That all the world will be in love with miglt,

And pay no worship to the garish sun.

William SHAKespeARE, ROMEO AND JULIET act 3, sc. 2, 11. 21-25. 


\section{INTRODUCTION}

Religion and politics, the ancient adage advises, are not proper topics for polite conversation. It is no surprise, then, that arguments about the proper relationship between religion and politics often generate more lieat than liglit. Indeed, few issues are more enduringly controversial than the role of religion im American public life. ${ }^{1}$

This controversy often rises to constitutional dimensions when an individual claims that the government has violated the Establishment Clause by actimg to proinote religion. Unfortunately, the Supreme Court's atteinpts to address this controversy have yielded infamously inconsistent results. ${ }^{2}$ In fact, the Court seems unable to develop even a set of unifying principles to guide its decisionmaking in this area. ${ }^{3}$

Furthermore, the controversy surrounding Establishment Clause issues is likely to continue because religion plays an increasingly important, thougli paradoxical, role in American public life. Statistics slow that Americans are among the inost religious people in the world. ${ }^{4}$ More than $94 \%$ of Americans believe in God or a universal spirit, $571 \%$ believe in heaven, and $53 \%$ believe in 11ell. ${ }^{6}$ More than $40 \%$ of Americans attend churcli or synagogue weekly, ${ }^{7}$ with college graduates more likely

1. See, e.g., Wiliam J. Gould, Jr., The Challenge of Liberal Political Culture in the Thought of John Courtney Murray, 19 CommuNo 113, 113, (1992) ("Throughout the past decade, the question of the proper place of religion in American public life has become a source of growing debate."); Douglas Laycock, Equal Access and Moments of Silence: The Equal Status of Religious Speech by Private Speakers, 81 Nw. U. L. REv. 1 (1986) ("The role of religion in the public schools is one of the most controversial issues of our time.").

2. See, eg., County of Allegheny v. ACLU, 492 U.S. 573 (1989) (prohibiting the display of a crèche but permitting the display of a menorah on public property); Lynch v. Donnelly, 465 U.S. 668 (1984) (permitting the display of a nativity scene on public property).

3. Academics have cominented at length on the inconsistency and incoherence of the Supreme Court's Establishment Clause jurisprudence. See Phillip E. Johnson, Concepts and Compromise in First Amendment Religious Doctrine, 72 CALIF. L. REv. 817, 839 (1984) ("Doctrinally, first amendment religion law is a mess."); Steven D. Smith, Separation and the "Secular": Reconstructing the Disestablishment Decision, 67 TEX. L. REv. 955, 956 (1989) ("In a rare and remarkable way, the Supreme Court's establishunent clause jurisprudence has unified critical opinion: people who disagree about nearly everything else in the law agree that establishment doctrine is seriously, perhaps distinctively, defective."); Mark Tushnet, The Constitution of Religion, 18 CoNN. L. REv. 701, 701 (1986) ("The constitutional law of religion is in significant disarray.' ").

4. "Americans ranked at the top in rating the inportance of God in their lives. On a scale of 1 to 10 , with 10 the highest, Americans average a rating of 8.21 , behind only tiny Malta (9.58)." George Gallup, JR. \& Jim Castelli, The PeOple's Religion: American Fatth IN THE 90's 47 (1989); see also Gary Wills, UNder God: Religion and American Politics 15 (1990) (noting that religion "has been slow to die in America").

5. New Christendom, Economist, Dec. 24, 1988, at 61,63 (citing Gallup polls) (noting that the percentage is unchanged since 1947).

6. Id.

7. Id. (compared with $37 \%$ in the $1930 \mathrm{~s})$. 
to go than high school dropouts. ${ }^{8}$ Furthermore, $78 \%$ of Americans pray at least once a week and $57 \%$ pray at least once a day. ${ }^{9}$ In fact, Americans reportedly invoke the deity more frequently than they go to work or have sex. ${ }^{10}$

At the same time, the standing of America's traditionally mainline Protestant churches has fallen. ${ }^{11}$ These churches are losing members in

8. Id. It is clear that "[t]hese statistics continue to astound European sociologists, particularly those whose experience of America is confined to the relatively secular West Coast and Boston-Washington corridor." Id. An even more astounding measure of American religiosity comes from a comparison between the pattern of religious behef in the United States and in other developed countries. Usually, religious betief decreases as economic developnent increases. If the usual pattern held true in the United States, only 5\% of people would say that religion is very important to them. The actual percentage of people in the United States who ascribe great iniportance to religious belief is $51 \%$. KENNETH D. WALD, RELIGION AND Politics IN THE United States 6-7 (1987). But see Andrew M. Greeley, The Catholic Myth: The Behayior AND Beliefs of AMERICAN CATHolics 265-71 (1990) (European Catholicism is also more resilient than is conmuonly believed, and by extension, secularization is not as certain as is supposed).

9. Kenneth L. Woodward, Talking to God, NEwSwEEK, Jan. 6, 1992, at 38, 39 (citing NORC study conducted by Andrew M. Greeley). In fact, $32 \%$ of Americans report having mystical prayer experiences. Id. at 42 (citing a 1986 survey conducted by Andrew M. Greeley). Even inore surprisingly, 20\% of atheists also report "praying" daily. Id. at 39 . There is also evidence that American bibhical hteracy is increasing. See, e.g., Robert N. Bellah, Christian Faithfulness in $a$ Pluralist World, in Postmodern Theology: Christian FaIth in a Pluralist World 74, 80 (Frederic B. Burnham ed., 1989) (citing Gallup statistics indicating that (1) in 1954, only 34\% of Americans knew who delivered the Sermon on the Mount while $42 \%$ knew in 1982; (2) in 1954, only $35 \%$ of Americans could name all four gospels while $46 \%$ could in 1982; and (3) in 1944, only $10 \%$ of Americans read the Bible daily while $15 \%$ did in 1984). But see George A. Lindbeck, The Church's Mission to a Postmodern Culture, in POSTMODERN Theology: CHRIsTIAN FAITH IN A PIURALIST World, supra, at 37,37 ("When one looks at the past . . . the Bible is culturally preeninent. ... [But there has been a] dramatic weakening of that role inside and outside the churches in the recent past."). For anecdotal evidence in support of Lindbeck's view that biblical literacy is declining, see WILLS, supra note 4, at 18 ("At an Operation Rescue rally, a journalist joined a group of other reporters with the breathless announcement that anti abortionist Randall Terry was telling bloodtlirsty stories about murder and disniemberment to avenge a rape. She did not know, though Terry had named the passage (Judges 19), that he was telling a Bible story, the tale of the Levite's concubine.").

10. Woodward, supra note 9 , at 39.

11. See Richard J. Neuhaus, The Naked Public Square: Religion and Democracy IN AMERICA 240-47 (1984) (arguing that liberal Protestantisin has "sold out" to an internally incoherent secularism); ROBERT WUTHNOw, THE RESTRUCTURING OF AMERICAN RELIGION 7199 (1988) (studying the decline of the principal Protestant denominations); see also NaNCY $T$. AMmerman, Baptist Battles: Social Change aNd Religious Conflict in the Southern BAPTIST Convention (1990) (discussing liow an essentially mainline Protestant denomination was taken over by neenbers with nore fundamentalist views). 
general ${ }^{12}$ and younger members in particular. ${ }^{13}$ More importantly, these churches no longer have many of the resources that made them a cultural mainstay in the past. ${ }^{14}$

But this reduction in the standing of traditional Protestant churches has not decreased religion's importance in American public life. While the number of Americans who belong to traditional, mainline churches has decreased, inembership in Catholic and "fundamentalist" churches has increased. ${ }^{15}$ Although the Catholic and the fundamentalist visions often vary widely, ${ }^{16}$ both the Catholic and the "fundamentalist" theologies contemplate a role for religion in public life and in the political process that is at least as prominent as the role contemplated by traditional Protestant denominations. This trend suggests that religion remains a vital component of American culture and that the Supreme Court, therefore, will probably have to decide Establishment Clause cases for many years to come.

Accompanying these demographic trends may be changes in how Americans define the proper role of religion in public life. Although it may be legitimate for fundamental changes in societal values to affect interpretation of the Religion Clauses, the interpretation should reflect the drafters' assumptions about reality unless those assumptions are clearly invalidated or rejected. The Religion Clauses embody the drafters' understanding that religion plays a particular function in American society and that some government interaction with religion is necessary to fulfill that function. Since that function is essentially the same today as it was then, the Supreme Court's Establishment Clause jurisprudence should acknowledge that only soine government interaction witl religion implicates the Establishment Clause, while soine does not.

Paradoxically, the Court has ignored this original understanding in

12. See H. Paul Chalfant et al., Religion in Contemporary Society 455 (1981) ("[I]n the period from 1965 to 1970 Methodists, United Presbyterians, Episcopalians, Lutherans ... and the United Church of Christ began to suffer declines in membership. In the next five years, from 1970 to 1975 " other mainline churches followed suit); WADE C. ROOF \& WILLIAM MCKINNEY, American Mainline Religion: Its Changing Shape and Future (1987) (statistical support for the decline of mainline churches); ROBERT WUTHNOW, THE STRUGGLE FOR AMERICA's Soul: Evangelicals, Liberais, ANd Secularism 111-12 (1989) (the rate of Protestant Church membership declined between 1952 and 1981).

13. Jolin A. Coleman, Is There a Catholic Moment in American Culture?, 25 Listening 9, 14 (1990) [hereinafter Coleman, Catholic Moment] ("Liberal Protestant churches are especially weak in maintaining the children of church members."); John A. Colenan, Young Adults: $A$ Look at the Demographics, CommonweAL, Sept. 14, 1990, at 483, 484 (statistics showing that evangelicals and Cathohics most successfully retain their children as church members).

14. See Neuhaus, supra note 11, at 241-47 (lamenting the drift of "[t]he heirs of the great culture-defining tradition" of mainline Protestantism, id. at 242); Coleman, Catholic Moment, supra note 13, at 13 ("The liberal Protestant decline is as much a matter of ethos as numbers.").

15. Coleman, Catholic Moment, supra note 13, at 14-15.

16. WUTHNow, supra note 12, at 42-43 (noting that religious liberals and religious fundamentalists often take opposite positions on political issues and that so-called religious liberals more often embrace the Catholic faith than do more conservative "fundamentalists"). 
its attempts to be excessively principled. All of the Justices behieve that a single Establishment Clause standard should apply to government action involving religion, but they disagree about whiat the proper standard should be. So the Court lias acknowledged at least three possible tests that could logically apply to any situation where the government interacts with religion. Which test is applied in a given case depends on the fact pattern and on which Justice writes the majority opinion.

However, it is impossible to encapsulate the values enshrined in the Establishment Clause in any succinct slogan or a tidy test that covers the myriad fact patterns raised in Establishment Clause claims. When confronted with this reality, the Court lias sought to avoid intuitively unacceptable Establishment Clause results either by manipulating the definitions of terms in whatever test it applies or by simply declining to apply the test rigorously. But this approach has yielded precisely the undesirable results and incolierent rationales that the Court hoped to avoid.

These probleins in current Establishment Clause jurisprudence can be remedied by relying on concepts drawn froin the sociology of religion. Sociology studies religion as an existing social reality. It tries to understand both the drafters' understanding of rehigion's function and religion's function in society today. This Cominent rehes on two prominent paradigms in the sociological study of American rehigion to develop a frainework that courts can use to evaluate Establishment Clause claims.

Part II will highlight the need for a new franiework by noting the incolierence of current Establishment Clause jurisprudence. Even where the Justices can agree on a simgle test to apply, no single test adequately addresses Establishment Clause values. Furtliermore, none of the existing tests can be applied effectively by the courts.

Part III will justify the proposed new franiework by showing why existing social reality is a legitimate reference poimt for current Establishment Clause jurisprudence. It argues, first, that the Religion Clauses as written embody the drafters' assumptions about reality and that these assumptions should not be discarded absent clear evidence that they are no longer valid. Second, sociology provides the most useful concepts with whicli to assess the drafters' understanding of religion's function. Third, religion's unique function in American society is essentially the saine today as the drafters understood it to be when the Constitution was adopted. Fimally, the courts are coinpetent to apply these concepts effectively to reach Establishment Clause decisions.

Part IV presents the two major sociological insiglits. The first is a conception of American society as a society that consists of three sectors: the state, the market, and civil society. Civil society promotes certam values that are essential to the survival of democracy. Because civil soci- 
ety is threatened by the imperialistic expansion of the market and the state, this sector deserves special protection.

The second major sociological insight is the identification of an American civil religion that fits within the three-sector model. Civil rehgion and civil society are opposite sides of the same coin. Civil society identifies the role of public institutions in forming private values that reinforce democracy, while civil rehgion pubhicly commemorates the role of certain private behefs about the country in order to reinforce democracy. Like the concept of civil society, the concept of civil rehigion identifies certain values that are essential to the identity of American democracy. To ensure this preservation of civil religion, government practices facilitating civil religion should be exempt altogether from Establishinent Clause analysis. ${ }^{17}$

Part V will evaluate current Establishinent Clause tests with these sociological insights. It will deinonstrate that these tests are all undesirable because they ignore the function of religion in American society.

Part VI applies this framework to two types of government practices. The first type is "public acknowledgment" of rehigion. This category consists of practices, like legislative prayer, prayer at school graduations, and the display of religious symbols at school graduations, that serve a largely ceremonial function. The second type is government financial support for rehion.

\section{II}

\section{The Need for a New Establishment Clause FRAMEWORK}

A brief recapitulation of the three most prominent Estabhishinent Clause tests embraced by current members of the Court will provide a useful background for the discussion that follows. The weaknesses of these tests accentuate the need for a new framework for Establishinent Clause adjudication.

\section{A. The Lemon Test}

The legal test under which Estabhishinent Clause claims have been evaluated for the past two decades was first articulated in the 1971 case of Lemon v. Kurtzman. ${ }^{18}$ In Lemon, the Court invalidated educational programs in both Pennsylvania and Rhode Island in which the state

17. The idea that the concept of civil religion should be applied to Establishment Clause adjudication has been suggested before. See Yehudah Mirsky, Note, Civil Religion and the Establishment Clause, 95 YALE L.J. 1237 (1986). This Comment differs from that Note in a number of ways. First, this Comment attempts to provide a more rigorous sociological definition of civil religion. More importantly, this Comment places civil religion in the broader context of a threesector model of society. That model provides a means of analyzing cases that do not involve civil rehigion, an analysis that Mirsky does not employ.

18. 403 U.S. 602 (1971). 
reimbursed parochial schools for some of the teacher salaries and administrative expenses incurred in teaching certain secular subjects. The Lemon test requires that "[f]irst, the statute inust have a secular legislative purpose; second, its principal or primary effect inust be one that neither advances nor inhibits rehioion; finally, the statute must not foster 'an excessive government entanglement with religion." "19 A statute violates the Establishment Clause if it fails any prong of that three-part test, which the majority culled from the "cumulative criteria developed by the Court over many years." 20

Each prong of the Lemon test presents analytic problems. The first prong is difficult to apply consistently because the term "purpose" is not clearly defined. The tern "purpose" can mean either a legislator's subjective intentions or the legislation's objective goal. But either meaning is problematic. $^{21}$

If purpose means lawmakers' subjective intentions, then the prong simply encourages lawmakers to be dishonest in expressing their motivations. Furthermore, even if a simgle legislator's actual motivations could be determined accurately, the purpose prong would still be difficult to apply because legislators may have differing purposes for enacting a statute or a smgle legislator may act for multiple reasons.

If purpose means the objective goal of the legislation, the first prong of the Lemon test is unworkable because it provides no criteria for determining and weighing the importance of competing goals. Even worse, the Lemon forinulation does not exphicitly distinguish between intent to achieve rehigious objectives and intent to use rehigious means to achieve a secular objective. If a legislator acts for secular reasons, such as courtimg the favor of an important group im her district, but her actions are quite sectarian, it might not be clear whether the purpose is rehigious. ${ }^{22}$ Similarly, if the legislature passes a bill designed to aid nonprofit hospitals, most of which are religious, it would not be clear from the Lemon test whether the purpose is to aid hospitals or to aid religion. So courts are left to choose between possible evils according to their own notions of what the Estabhishinent Clause should allow.

It is no surprise, then, that courts have not applied the purpose prong consistently. As Justice Scalia wrote in Edwards v. Aguillard: $:^{23}$

Our cases interpreting and applying the purpose test have made such a maze of the Estabhishinent Clause that even the most con-

19. Id. at $612-13$ (citations omitted).

20. Id. at 612 .

21. Despite the difficulties in discerning purpose, the Court does so all the time when interpreting statutes. See William N. Eskridge, Jr., Politics Without Romance: Implications of Public Choice Theory for Statutory Interpretation, 74 VA. L. REv. 275, 275-78 (1988) (explaining different approaches to determining purpose in statutory interpretation).

22. See Johnson, supra note 3 , at 827 .

23. 482 U.S. 578 (1987). 
scientious governmental officials can only guess what motives will be held unconstitutional. We have said essentially the following: Government may not act with the purpose of advancing rehgion, except when forced to do so by the Free Exercise Clause (which is now and then); or when eliminating existing governmental hostility to religion (which exists sometimes); or even when merely aceommodating governmentally uninhibited religious practices, except that at some point (it is unclear where) intentional accommodation results in the fostering of rehigion, which is of course unconstitutional. ${ }^{24}$

The second prong of Lemon is also conceptually confusing. First, it is unclear what level of assistance must be given before religion is "advanced." More importantly, an Establishment Clause claim could never involve an inhibition of religion. Estabhishment Clause arguments, by their very nature, claim that government has done too much for religion, not too hittle. A statute that inhibited religion might inplicate the concerns of the Free Exercise clause, but it would not violate the Estabhishment Clause. ${ }^{25}$

The "excessive entanglement" prong is no more lielpful. It is not really an objective criterion at all, since the Court has never defined what constitutes entanglement or specified how much entangleinent is too much for Estabhshment Clause purposes. More fundamentally, the Court has never explained convincingly why excessive entangleinent is an essential part of an Establishment Clause test. As a result, the excessive entangleinent prong has served merely as a vehicle through which the Court can invalidate legislation or activities that pass the first two prongs of Lemon but that the Court deems inappropriate. ${ }^{26}$

\section{B. The Endorsement Test}

Justice O'Connor has declared lier dissatisfaction witl Lemon and proposed her own alternative. O'Connor's "endorsement test" essentially is a modification of Lemon. It retains some minimal scrutiny of legislative purpose. O'Connor would ask whetler the asserted justifications for the legislation-not the actual motives of the legislators-are religious. In other words, her test requires only that there be some plausible secular justification for the legislation.

The original contribution of the endorsement test, however, is the

24. Id. at 636 (Scalia, J., dissenting).

25. See Douglas Laycock, Towards a General Theory of the Religion Clauses: The Case of Church Labor Relations and the Right to Church Autonomy, 81 CoLum. L. REv. 1373, 1378-81 (1981).

26. See Jesse H. Choper, The Religion Clauses of the First Amendment: Reconcling the Confict, 41 U. PITT. L. REv. 673, 673-81 (1980) (noting "[t]he conceptual chaos forged by the Court's test-effectively attributable to its 'entanglement prong' "-and contending that the Court lacks any "principled rationale for its product," $i d$. at 681 ). 
content that it tries to give to the second prong of Lemon. Instead of asking whether the government practice "advances" religion, the endorsement test asks whether the practice "endorses" religion.

This test is derived from O'Connor's different view of First Amendment values. O'Connor believes that the Establishment Clause is meant to protect the equal standing of citizens in the political community. ${ }^{27}$ Based on this belief, she concludes that an unacceptable endorsement of religion occurs whenever a reasonable observer may fairly understand that a government action "sends a inessage to nonadlierents that they are outsiders, not full ineinbers of the political community."28

But the endorsement test is also problematic for two reasons. First, the nature of the "reasonable observer" has been questioned. If the endorsement test is to protect members of the minority froin being treated as less than full members of the political commumity, the reasonable observer must be a reasonable meinber of the minority. If the reasonable observer is a member of the majority, the test "will be inadequately sensitive to the impact of government actions on religious mimorities, thereby in effect basing the protection of religious mimorities on the judgment of the very inajority that is accused of infringing the minority's religious autonomy." 29

But if the observer is a reasonable member of a minority religion, then there is a risk that the Court will rely on mere subjective opimions about what constitutes an Establishment Clause violation. Furtler, this shift in focus still does not meet the inajoritarian objection. Retaining the word "reasonable" means that the Court's judgments will still rely on the opinions of the "reasonable" minority member. But reasonableness has to be determined with reference to some commonly-accepted standards withm that minority community, so the individual's rights might still be threatened.

A second criticisin of the endorsement test focuses on the ineaning of endorsement. Critics contend that the term's lack of definition makes the test ineffective as a guide to the Court in these cases. ${ }^{30}$ If endorsement is not defined, then the endorsement test is no more helpful than Lemon's effect prong.

\section{The Coercion Test}

The third possible Establishment Clause standard is Justice Kennedy's coercion test. In County of Allegheny v. $A C L U,{ }^{31} \mathrm{Kemiedy}$

27. Lynch v. Donnelly, 465 U.S. $668,687-88$ (1984) (O'Connor, J., concurring).

28. Id. at 688 .

29. Note, Developments in the Law: Religion and the State, 100 HARV. L. REv. 1606, 1648 (1987) (discussing government use of religious symbols in public life).

30. See, e.g., William P. Marshall, "We Know It when We See It": The Supreme Court and Establishment, 59 S. CAL. L. REv. 495, 537 (1986).

31. 492 U.S. 573 (1989). 
argued that the Establishment Clause is violated only when a statute or practice coerces an individual to believe a particular doctrine. According to Kennedy, coercion is not necessarily limited to direct coercion, but 1nay also be indirect. ${ }^{32}$ Indirect coercion nnight occur, he suggested, if the government spent "significant amounts of tax inoney to serve the cause of one religious faith," or if government accommodations of religion "represent an effort to proselytize or are otherwise the first step down the road to an establishment of religion." 33

A stricter standard than coercion, Kennedy suggests, would hinder "[ $t]$ he ability of the organized community to recognize and accommodate rehigion in a society with a pervasive public sector." 34 According to Kennedy:

[A]s the inodern administrative state expands to touch the lives of its citizens in such diverse ways and redirects their financial choices through prograins of its own, it is difficult to inaintain the fiction that requiring government to avoid all assistance to rehgion can in fairness be viewed as serving the goal of neutrality. ${ }^{35}$

Like the Lemon and endorseinent tests, Kennedy's coercion test has been severely criticized. The critiques have focused on three inain points. First, opponents of the test contend that it iguores the plain words of the Amendment, which forbid not just establishment, but everything respecting an establishment of religion. ${ }^{36}$ Second, critics argue that the coercion test eliminates the distinction between the Free Exercise Clause, under which coercion of behief is the ineasure of a violation, and the Establishment Clause. Finally, the coercion test has been condemned as a completely ahistorical misrepresentation of the founders' beliefs. ${ }^{37}$

Froin this brief review, it is evident that the three nost prominent Estabhishment Clause tests have many analytical probleuns that inake thein difficult to apply. More fundamentally, it is not at all clear that they adequately uphold the values that the Estabhishinent Clause was meant to protect. The next Part will begin the task of developing a framework that should avoid both of these criticisins.

32. Id. at 661 (Kennedy, J., concurring in the judgment in part and dissenting in part).

33. Id. at 664 .

34. Id. at 659 .

35. Id. at 657-58.

36. U.S. CoNST. amend. I ("Congress shall make no law respecting an establishment of rehigion, or prohibiting the free exercise thereof ....").

37. For a brief summary of these principal points, see Brief for National PEARL (National Education Association, National PTA, et al.) and the National Association of Elementary School Principals as Amici Curiae in Support of Respondents at 18-25, Lee v. Weisınan, 112 S. Ct. 2649 (1992) (No. 90-1014). 


\section{III}

\section{JUSTIFICATION FOR THE SOCIOLOGICAL APPROACH TO ESTABLISHMENT ClaUSE AdJUdication}

A coherent approach to Establishment Clause adjudication should be informed by the values at the heart of the constitutional provisionthe impulse behind its inclusion in the First Amendment. As many commentators have noted, the primary Establishment Clause value at stake is religious liberty. ${ }^{38}$ The Religion Clauses, therefore, are designed both to protect the conscience of the individual and to prevent the state from interfering with the autonomy of religion. ${ }^{39}$

But to understand what it means to protect the conscience of the

38. See, eg., Jesse H. Choper, The Establishment Clause and Aid to Parochial Schools, 56 Calif. L. Rev. 260, 267 (1968). The emphasis on religious liberty also makes sense as a matter of history. It is important to recognize, though strict separationists seldom do, that the idea of the separation of church and state originated in the church, not in the state. Gerard V. Bradley, The Enduring Revolution: Law and Theology in the Secular State, 39 EMORY L.J. 217 (1990) (review essay). According to Bradley:

The uniquely Western notion of two jurisdictions, including an autonomous temporal order of civil regulation, was produced entirely by Christian theological reflection. Eleventh-century ecclesiastical reformers, who inhabited an undifferentiated realm of sacralized kingship and worldly prelates, sought a more authentic Christianity by separating church from empire. Medieval history, frequently depicted as beset by theocratic regimes, was instead one long struggle by the church to free itself of royal domination.

Id. at 217 (footnote omitted); see also Gould, supra note 1, at 117 ("[T]he distinction between the sacred and the secular orders meant that human existence was under the authority of two distinct powers, one ecclesiastical and one civil, each supreme in its own sphere-the Gelasian principle of the two swords.... [T] he basic dualism separating the two orders ... must be respected."); J. Bryan Hehir, The Right and Competence of the Church in the American Case, in ONE HUNDRED YEARS OF Catholic Social Thought: Celebration and Challenge 55 (John A. Coleman ed., 1991) (detailing the recent history of the Catholic Church's struggle for an imdependent role in society). In the American context, Roger Williams was an early proponent of the separation of church and state-not for the well-being of the state, but rather for the purity of the church. See GEORGE M. Marsden, Religion and American Culture 19 (1990); Timothy L. Hall, Roger Williams and the Foundations of Religious Liberty, 71 B.U. L. REv. 455, 457-58 (1991). When he visited the United States in the 1830s, Alexis de Tocqueville found unanimous support aniong the clergy for the idea of the separation of church and state:

[I]n America, I found [that the spirits of religion and freedom] were intimately united and that they reigned in common over the sanie country. My desire to discover the causes of this phenomenon increased from day to day. In order to satisfy it I questioned the mernbers of all the different sects; I sought especially the society of the clergy .... I found that they differed upon matters of detail alone, and that they all attributed the peaceful dominion of religion in their country mainly to the separation of church and state. I do not hesitate to affirm that during my stay in America I did not meet a simgle imdividual, of the clergy or the laity, who was not of the same opinion on this point.

1 ALEXIS DE TocqueVILle, Democracy IN AMERICA 308 (Henry Reeve trans., Vintage Classics 1990) (1835). There is still a strong consensus on this point today. See, e.g., Janies E. Wood, Jr., Religious Pluralism and American Society, in ECUMENICAL Perspectives ON ChURCH AND STATE 1, 14-16 (Janies E. Wood, Jr. ed., 1988).

39. While common, this view is not unanimous. Justice $O^{\prime} C o n n o r$, for example, has a very different view of the values at the heart of the Establishment Clause. O'Connor believes that the Clauses should ensure equal standing in the political community aniong adherents of different faiths. Lynch v. Donnelly, 465 U.S. 668, 687-88 (1984) (O'Connor, J., concurring). 
individual and the autonomy of religion, it is necessary to understand the role that religion plays in society and how religion's role differs from the government's. This Part justifies the proposed sociological framework by developing four related arguments. First, the drafters' assumptions about reality should inform current interpretation of the Rehigion Clauses unless it becoines clear that those assumptions are no longer valid or accepted. Second, sociology provides the inost useful concepts for assessing the drafters' understanding of the reality of rehigion's function in society. Third, the drafters' particular sociological understanding of religion's unique function in society remains largely accurate today. Finally, the Courts are coinpetent to identify and apply insights from this sociological understanding to guide Establishınent Clause decisionmaking.

\section{A. Original Intent as the Primary Guide to Constitutional Interpretation}

Before beginning this discussion, a brief word is needed on what is meant by "original intent." As used in this Coinınent, it does not mean the subjective inotivations of the drafters. Any attempt to ascertain these motivations would founder on the same probleins that plague the Lemon test's purpose prong. Similarly, it does not mean inerely a "snapshot" of the founders' world that can be transposed into our own. ${ }^{40}$

Instead, original intent as used here means "plain meaning historically recovered." ${ }^{41}$ This approach to constitutional interpretation posits that the plain ineaning of a constitutional provision can be understood only by determining what the plain ineaning of the provision was when it was inserted into the Constitution. While this approach does not deny that the provisions in the Bill of Rights represent substantive principles, it seeks to discover what the principles underlying the provisions meant at the time that they became part of the Constitution before applying those principles and the provisions theinselves to modern circumstances.

This focus on meaning at the time of adoption reflects a sensitivity to the herneneutical lesson that all meaning is contextual. ${ }^{42}$ People live in communities and the meaning of their words and actions can be understood only in the context of those communities. As Micliael Perry notes, "The extent to which one's most basic . . . beliefs are rooted in the coinmunities and traditions in which one participates bears einphasis. Basic ... beliefs ... are less the property of individuals than of comınuni-

40. Gerard V. Bradley, The Bill of Rights and Originalism, 1992 U. ILL. L. REv. 417, 420 (discussing the "defective originalism" that occurs when "constitutional meaning is sought in a snapshot of the world as it was in about 1790").

41. II. at 424 .

42. Id. 
ties." ${ }^{43}$ The basic beliefs of the founders about the proper role of religion in society-beliefs that animate the Establishment Clause-cannot be understood without understanding the community and society in which the founders lived.

Given these propositions, the original ineaning of the Establishment Clause can be examined. Despite the inodern tendency to think of the Bill of Riglts as the einbodiment of all of our "aspiration[s] to social justice, brotlerliood, and liuman dignity,"44 it is inescapable that at the time it was passed, the Bill of Rights was certainly not that. ${ }^{45}$ Instead, the Bill of Rights served merely to limit the power of the federal government. ${ }^{46}$ The Bill of Riglits was appended to the Constitution not as "a sublime oration on the dignity of man,"47 but rather as part of a compromise solution to a bitter political battle. ${ }^{48}$ Indeed, James Madison viewed the Bill of Rights not as "the lodestar of our aspirations"49 but rather as a "nauseous project." 50

The Bill of Rights emerged out of the dispute between the Federalists and the Anti-Federalists over the true origin of the Federal Constitution. The Anti-Federalists argued that the new Constitution was formed by individuals coming out of the state of nature. ${ }^{51}$ According to this view, any rights that individuals failed to retain specifically would be given to the new national government..$^{52}$

In contrast, the Federalists argued that the new federal government was formed by people acting through the individual states. According to this view, the Constitution granted only limited powers to the federal government, and the people reserved all other riglits. ${ }^{53}$ This view explains why Madison described the Constitution as a "Bill of Powers [that] needs no bill of R[igli]ts," ${ }^{54}$ and why the Federalists considered the protection of individual rights to be the province of the states. ${ }^{55}$ It also

43. Michael J. Perry, Moral Knowledge, Moral Reasoning, Moral Relativism: $A$ "Naturalist" Perspective, 20 GA. L. REv. 995, 1032 (1986).

44. William J. Brennan, Jr., The Constitution of the United States: Contemporary Ratification, 27 S. TEX. L. REV. 433, 433 (1986).

45. See John E. Nowak, The "Sixty Something" Anniversary of the Bill of Rights, 1992 U. ILL. L. REv. 445, 445-50 (arguing that the Bill of Rights as originally passed did hittle to protect individual rights).

46. Id. at 447-48.

47. Brennan, supra note 44 , at 438 (referring to the Constitution as a whole).

48. See James H. Hutson, "A Nauseous Project," W1LsoN Q., Winter 1991, at 57 (outlining the process by which the Bill of Rights was ratified and the substantive disagreements among the drafters about specific provisions to be inserted or omitted).

49. Brennan, supra note 44 , at 433 (referring to "[o]ur amended Constitution").

50. Hutson, supra note 48 , at 69 .

51. Id. at 64 .

52. Id. at 64-65.

53. Id.

54. Id. at 65 .

55. Id. 
helps explain the curious form of the Bill of Rights itself. Drafted by Madison, the rights were expressed as limitations on the reach of governmental power rather than as affirmative entitlements. The Bill of Rights was added to the Constitution as a concession to the Anti-Federalists to ensure passage of the Constitution. ${ }^{56}$

Whatever the Bill of Rights may have come to represent today, then, it is clear that it did not embody the Founders' version of social engineering. It was not an attempt to construct some version of the ideal society. Instead, it was concerned, like the rest of the Constitution, with creatimg and limitimg government.

The Establishment Clause itself provides the perfect example of this focus. Despite its prohibition of estabhished churches, the Clause left undisturbed the churches that were officially established in most of the states. ${ }^{57}$ Religion's role in society was not restricted by the Estabhishment Clause; only religion's interactions with the new federal government were limited. Indeed, the Clause was designed in part to protect religion's autonomous role in society and in public life from intrusion by the government.

To fully understand the original meaning of the Establishment Clause, it is essential to understand exactly what the founders understood rehion's autonomous role in society to be when the Constitution was drafted. This understanding sliould inform current construction of the Clause unless it becomes clear that the drafters' understanding of religion's role and function in society is no longer valid. ${ }^{58}$

\section{B. Usefulness of Sociology to Assess the Drafters' Understanding of Religion's Unique Function in Society}

Sociology provides the most useful analytical tools with which to assess the drafters' understanding of religion's unique role in society. As a theoretical matter, the whole purpose of sociology is understanding existing social reality. It studies the social role of yarious imstitutions and explores shared norms, values, and hifestyles. These shared norms and judginents are perhaps the best avenue to understanding the principles that animated the Establishment Clause originally.

Sociologists have devoted considerable attention to studying religion in the United States. Indeed, the sociology of religion is suited to this kind of inquiry in a way that, for example, economics is not, because other disciplines have not so deliberately brought their analytic resources

56. Id.

57. See Robert L. Cord, Separation of Church and State: Historical Fact and CuRRENT Fiction 15 (1982).

58. See, e.g., Lynch v. Donnelly, 465 U.S. 668, 673 (1984) ("The Court's interpretation of the Establishment Clause has comported with what history reveals was the contemporaneous understanding of its guarantees."). 
to bear on studying religion in particular. ${ }^{59}$

\section{The Congruence Between the Drafters' Understanding of Religion's Function in Society and Religion's Function in Society Today}

The Supreme Court lias suggested in some of its opinions that it recognizes religion's continuing function in society and that an understanding of this function should guide Establishment Clause construction. When confronted with government practices that inight be unconstitutional according to a strict application of the Lemon test, the Court has declined to apply the test strictly. Instead, it has relied on a historical analysis in deciding to uphold certain rehgious practices.

For example, in both Marsh v. Chambers ${ }^{60}$ and Lynch v. Donnelly, ${ }^{61}$ the Supreme Court turned to history to determine the constitutionality of certain government interactions with religion. In Marsh, the Court relied on the historical practice of the first Congress to uphold the continued use of legislative cliaplams. ${ }^{62}$ In $L y n c h$, the Court looked to historical practice to determine the validity of a Christınas crèclie display. ${ }^{63}$

This adjudicative metlod is a poor one because it sheds no light on the ineaning of, or principle behind, the Establishment Clause. Instead, it rehes simply on analogies with past practices-analogies that are imperfect and that produce wildly inconsistent results. Nevertleless, it seems to at least acknowledge that the context in which the Establishment Clause was drafted should guide its interpretation today.

The Court's metliod of historical analysis would be improved if the Court rehed on plain meaning historically recovered instead of on analogies. A study of the plain meaning of the Establishinent Clause reveals that religious hiberty is the animating principle behind the Clause. ${ }^{64} \mathrm{But}$ the phrase "religious hberty" slould be defined with reference to the role of rehioion in society at any given tine. This fuller understanding of religious liberty, rather than an impoverislied metlodology by analogy, should guide the Court.

This fuller understanding reveals that current social reality, as portrayed by the sociology of religion in particular, slould guide current

59. Even to the extent that some judges, academicians, and theorists dissent from the original intent view, the consideration of existing social reality serves as a way to bridge the gap between originalists and interpretivists. The approach to constitutional coustruction advocated here, though solidly grouuded in the drafters' understanding of the document, is not hopelessly stuck im an unimaginably different past. The approach advocated here is principled, but the principle is a dynamic one, capable of responding to changing social attitudes and norms. What the approach does require is a clear demonstration that understandings and assumptions about reality have changed sufficiently to justify departing from the framers' assumptions and understandings.

60. 463 U.S. 783 (1983); see infra Section VI.A.1.

61. 465 U.S. 668 (1984); see infra text accompanying notes 268-74.

62. Marsh, 463 U.S. at 786-92.

63. Lynch, 465 U.S. at $673-87$.

64. See supra note 38 and accompanying text. 
construction of the Clause because religion performs essentially the same functions today that it did when the Clause was drafted. As will be demonstrated in Part IV, rehgion was then, and is now, the most important institution in voluntary society. It is where inost Americans learn the basic values of lonesty, hard work, and mutual self-care tliat are necessary to sustain democratic government.

\section{The Competence of Courts to Apply Sociological Insights About Religion's Actual Function in Society}

It might be argued that it is not feasible to integrate sociological insights into the Court's jurisprudence because the Court is incapable of selecting the most helpful sociological concepts and then applying those concepts to guide decisionmaking. ${ }^{65}$ But neither the concept of civil religion $^{66}$ nor the three-sector mode ${ }^{67}$ is controversial or difficult to apply. Botli are traditional American understandings of low rehion functions in society.

Because there is no consensus on what methodology the Court should use to decide cases, this effective sociological avenue slould not be disregarded. ${ }^{68}$ Since neither scholars, judges, nor the Court itself can agree about what inethods are appropriate, it seems imprudent to overlook an established body of knowledge that offers the possibility of lend-

65. There is a vast literature on the institutional competence of courts. See, e.g., David L. Faigman, To Have and Have Not: Assessing the Value of Social Science to the Law as Science and Policy, 38 EMORY L.J. 1005, 1095 (1989) ("As science, the social sciences can provide the law only modest assistance. . . . At the same time, however, the significance of social science research should not be underestimated, for ultimately it provides a check on the suppositions of its critics as well as its proponents."); Daniel A. Farber \& Philip P. Frickey, The Jurisprudence of Public Choice, 65 TEX. L. REV. 873, 926 (1987) ("Use of interdisciplinary materials poses obvious dangers, but . . . [t]he alternative to the 'lawyer as astrophysicist' is sometimes the 'lawycr as astrologer,' clinging to outmoded notions while ignoring contemporary knowledge.").

66. See infra Section IV.B.

67. See infra Section IV.A. For examples of work based on the three-sector model of society, see Robert N. Bellah et al., The Good Society (1991); Alan Wolfe, Whose KeEper? Social Science aNd Moral Obligation (1989).

68. The Court, judges, and scholars cannot agree about low the Constitution should be interpreted. See, e.g., ROBERT H. BORX, THE TEMPTING OF AMERICA $251-60$ (1990) (arguing that originalism is the only legitimate interpretive stance for the judiciary); JOHN H. ELY, DEMOCRACY AND Distrust: A THEORY OF JUDICIAL REVIEW (1980) (arguing for a non-originalist interpretation that polices the process of representation by clearing channels of political change and facilitating the representation of minorities); Michael J. PERRY, THE CONSTITUTION, THE COURTS, AND HUMAN RIGHTS 163 (1982) (developing a theory that cncourages judges to interpret the Constitution functionally in terms of moral reevaluation and moral growth).

It is also unpersuasive to dismiss the application of sociology to Establishment Clause questions because the nse of sociological methods might in some way taint the theological beliefs being examined. Theologians are quite comfortable with the application of social science to their field, although there is a lively debate about whether the role of the social sciences ought to be merely supplementary or equal to theology in theology's understanding of itself. See Paul Rigby et al., The Nature of Doctrine and Scientific Progress, 52 Theological STuD. 669 (1991) (describing the debate between those who argue that social sciences must reinain ancillary to scripture and those who envision egalitarian exchange). 
ing coherence to the Court's cases and ensuring that decisions are not based on misconceptions of religion's role in America. ${ }^{69}$

\section{IV}

The Three-Sector Model of Society AND THE

CONCEPT OF CIVIL RELIGION AS GUIDES TO

ESTABLISHMENT CLAUSE

ADJUDICATION

\section{A. The Three-Sector Model: State, Market, and Civil Society}

Beginning with Alexis de Tocqueville, a ricli sociology has developed to explain the role of religion in American society. Under this view, Western democracies in general and American society in particular are divisible into three sectors: the market, the state, and civil society or the voluntary sector. ${ }^{70}$ The market is the portion of society characterized by economic activity. It emphasizes profit, cost/benefit analysis, the "bottom line," and efficiency. The "state" is the governing entity and includes all administrative apparatus and functions. In the Urited States today, the state reinforces imdividualism because citizens can assert both procedural and substantive rights against it. The state is also coercive in that it has the power to force people to obey its mandates.

"Civil society" is the voluntary sector of society, which includes churches, civic associations, cliaritable groups, religious hospitals, and private educational institutions. This sector is characterized by solidarity, joint commitment, personal responsibility, and inutual care. ${ }^{71}$ This sector is responsible for forming people's character and identity and for inculcating and instantiating values thiat are essential to a democratic government. ${ }^{72}$ Furtlier, in order to perform these functions that are

69. The Court frequently ends up engaging in its own ad hoc sociology anyway, so it might as well be honest and intellectually rigorous about it.

70. WuTHNOW, supra note 12 , at 5-8.

71. See Mary Ann Glendon \& Raul F. Yanes, Structural Free Exercise, 90 Mich. L. REv. 477, 537 (1991) (suggesting that the distinction between the individualistic language of the state and the communiatarian language of civil society ought to be relevant to Establishment Clause jurisprudence); see also Mary Ann Glendon, Religion \& the Court: $A$ New Beginning?, FIRST ThINGs, Mar. 1992, at 21. According to Glendon:

The problem is that, although we have a highly developed hinguistic and conceptual apparatus for thinking about and dealing with mdividuals, market actors, and the state, we lack adequate concepts to enable us to take into consideration the social dimensions of human personhood, and the social environments that individual men, women, and children require in order to flourish. Sociologists often use the somewhat cumbersome expression "mediating structures" to refer to what I prefer to call commumities, i.e., families, neighborhoods, religious groups, and other groups of memory and inutual aid.

Id. at 22 .

72. See, e.g., Georgie A. Geyer, Perils of a Free World, World MonITOR, Mar. 1992, at 28.

The terrible question, on which the jury is still out in this brave new world of unlimited hopes for everyone, is whether many societies now in the process of transformation from 
essential to democracy, this third sector must not be governed by the state nor the market.

Neither the state nor the market has the capacity to fulfill the functions of the third sector-civil society. Because it is coercive, the state cannot replace the voluntarism of civil society. Because it is based on profit maximization, the market cannot tutor the citizenry in altruism.

\section{The Origins of the Three-Sector Model: De Tocqueville's Early Observations on Democracy in America}

During his travels through the young United States in 1831, Alexis de Tocqueville observed religion's salutary effects on the life of the new nation. In Democracy in America, ${ }^{73}$ de Tocqueville emphasized the importance of religion and otler private associations in mitigating the dangers associated with democracy. Althougl he regarded the young America highly, de Tocqueville beheved that democracy was, in some respects, fragile and fraught with hazards.

\section{a. Individualism and Materialism as Threats to Democratic Government}

De Tocqueville coined the word individualism to describe the individual isolation tlrat he perceived in American society. According to de Tocqueville:

Individualism is a mature and calm feeling, which disposes each meniber of the community to sever himself fron the mass of his fellows and to draw apart with his family and his friends, so that after he has tlius formed a little circle of his own, he willingly leaves society at large to itself. Selfishness originates in blind instinct; individualism proceeds from erroneous judgment more than from depraved feehings; it originates as much im deficiencies of mind as in perversity of heart. ${ }^{74}$

Individualism leads to isolation. It destroys the fiber of public life and the sense of the common good. Ultimately, it deteriorates into selfishness and destroys the fabric of private life. Individualists "acquire the habit of always considering tliemselves as standing alone, and they are apt to

totalitarianism to freedom have the internalized value systems and civic moral principles necessary for the difficult shift to free enterprise and free politics.

....

... [C]ertain values-values that must be deeply ingrained-are necessary if a people want to make this unbossed economic and political system work. Id. at $30-31$.

73. DE Tocqueville, supra note 38 (2 vols.). This Comment refers frequently to Tocquevilleian concerns about democracy. While this language is helpful for purposes of this Comment, it is nonetheless important to note that de Tocqueville himself drew a clear distinction between equality as a social condition and democracy as a form of government. 1 id. at 3.16 (author's introduction).

74. 2 id. at 98. 
imagine that their whole destiny is in their own hands."75

Following the tradition of de Tocqueville, modern sociologists have commented on the continuing prommence of individualism in American life $^{76}$ and its continuing potential to threaten other important democratic values. ${ }^{77}$ On the one hand, individualism is "our deepest identity," intimately linked to "[o]ur highest and noblest aspirations, not only for ourselves, but for those we care about, for our society and for the world."78 On the other hand, as modern mdividualism "has pursued individual rights and individual autonomy in ever new realms," a way of life that is neither individually or socially viable," because it "weakens the very meanings that give content and substance to the ideal of individual diginty." 80 Individualism has now become such an absolute that it has almost completely eliminated from common consciousness the older biblical and civic republican notions of human identity which originally helped create individualism. ${ }^{81}$ Without these companion ideas, modern individualism exists in a dangerous void, and the self is considered " "the only or main form of reality." "82

De Tocqueville beheved that this radical individualism threatened democratic government because it undermined the kind of civic unity that made such government possible. As individualisin leads people to withdraw into smaller circles of interaction, their opporturities to learn the values that come through association with others diminish. In the long term, this trend threatens the survival of democratic government because it undermines the pohtical culture necessary to sustain that government. $^{83}$

Capitalism, another component of American society, promotes a spirit of materialism. Tocqueville found that Americans were "devotedly attached to the pleasures of material life," and called the "love of wellbeing" the "predommant taste of the nation."84 Indeed, he found something novel in the "bootless chase [by a whole people] of that complete

75. 2 id. at 99.

76. For a more recent description of American individualism, see ROBERT N. BELLAH ET AL., HABITS OF THE HEART: INDIVIDUALISM AND COMMITMENT IN AMERICAN LIFE 142-63 (1985) (analyzing individualism in contemporary American society).

77. Id. at 150 .

78. Id. at 142 .

79. Id. at 143 .

80. Id. at 144.

81. Id. at $142-43$.

82. Id. at 143 (quoting Robert Coles, Civility and Psychology, DaEDALus, Summer 1980, at 137).

83. 2 DE TocQueville, suprá note 38 , at 102-05. In contrast to democratic government, which depends on a flourishing communal life, despotism and atomism go together. "Despotism, which by its nature is suspicious, sees in the separation among men the surest guarantee of its continuance, and it usually makes every effort to keep them separate." 2 id. at 102.

84. 2 id. at 130 . 
fehicity which forever escapes [them]."85

This restless materialism, this American nervousness, poses two specific problems for the well-being of democracy. First, it consumes so much time and energy that citizens have little opportumity to attend to other concerns. ${ }^{86}$ Thus, the "market" governs increasingly large areas of life. Second, the movement from one location to another in pursuit of prosperity limits citizens' opportumities to settle im particular places and form the kinds of lasting ties that make deinocratic communities possible. $^{87}$

De Tocqueville's description of inaterialism, like his conception of individualism, is still eerily accurate today. ${ }^{88}$ Indeed, the conflicts between inaterialism and democracy lave intensified and become institutionalized. Materialism now threatens democracy not only because it creates individual restlessness that makes it difficult to form coinmunities, but also because a fundamental tension exists between democratic equality and a market system which institutionalizes economic precariousness. The American nuarket system in particular, mucli more than the European system, emphasizes individual economic prospertity-the combination of private affluence and limited public expenditures. Because economic life itself promotes individual isolation, it is hostile to the common good and, therefore, makes it mucl harder to realize any ideal of essential democratic community.

85. 2 id. at 137.

86. See BELLAF ET AL., supra note 76, at 22-23 (discussing the fact that Americans pursuing success in large corporations have limited opportunities for active involvement in family and community life).

87. De Tocqueville commented on the rootlessness provoked by Americans' quest for material gratification:

In America I saw the freest and most enlightened men placed in the happiest circumstances that the world affords; it seemed to me as if a cloud habitually hung upon their brow, and I thought them serious and almost sad, even in their pleasures.

In the United States a man builds a house in which to spend his old age, and he sells it before the roof is on; he plants a garden and lets it just as the trees are coming into bearing; he brings a field into tillage and leaves other men to gather the crops; he embraces a profession and gives it up; he settles in a place, which he soon afterwards leaves to carry his changeable longings elsewhere. If his private affairs leave him any leisure, he instantly plunges into the vortex of politics; and if at the end of a year of unremitting labor he finds he has a few days' vacation, his eager curiosity whirls him over the vast extent of the Uirited States, and he will travel fifteen hundred iniles in a few days to shake off his happiness.

2 DE TocQueville, supra note 38 , at $136-37$.

88. See Bellah ET AL., supra note 76, at 22 ("The means to achieve individual choice, [Americans] tend to think, depend on economic progress. . . . To be a success at work means to advance up the hierarchy...."). 


\section{b. Associations and Religion as Remedies for Individualism and Materialism}

In de Tocqueville's view, neither the endless quest for material gratification nor the isolation of individualism made American democracy unworkable. Although both phenomena could easily dissolve the fragile bonds of social union, American democracy was successful because it combatted the effects of capitalism and materialism. It did so primarily through an "immense asseinblage of associations," organized for nearly every imaginable purpose. ${ }^{89}$

Political associations in particular, which constituted only a small percentage of the associations, were deemed to be "large free schools, where all the members of the community go to learn the general theory of association." "90 According to de Tocqueville, associations empower citizens who would otherwise be powerless as individuals to achieve common goals. ${ }^{91}$ The ties formed in associations help create the essential bonds that form the basis of a viable society..$^{92}$

Rehigious associations are particularly valuable to the preservation of democracy because they imculcate not ouly the value of association itself, but also the specific attributes of rehigion. ${ }^{93}$ Rehigion "place[s] the object of man's desires above and beyond the treasures of earth and ... raise[s] his soul to regions far above those of the senses."94 These attributes play an important role in counteracting the dangers of individualism that arise in democratic cultures. De Tocqueville warned that "equality, which brings great benefits into the world, nevertheless suggests to men ... soine very dangerous propensities. It tends to isolate thein from one another, to concentrate every man's attention upon himself; and it lays open the soul to an inordinate love of material gratification."95 Involveinent in rehioious associations tempers the excesses of deinocratic life and teaches citizens that the principle of self-interest rightly understood includes soine recognition of hunian interdependence. ${ }^{96}$ Thus, de Tocqueville beheved rehion to be the first of America's political institutions because it facilitated the use of freedom. ${ }^{97}$

89. 2 DE TOCQUEVILLE, supra note 38 , at 106.

90. 2 id. at 116.

91. Some examples of associational goals in de Tocqueville's time were "to give entertainments, to found seminaries, to build inns, to construct churches, to diffuse books, to send missionaries . . . to inculcate some truth or to foster some feeling by the encouragement of a great example." 2 id. at 106.

92. 2 id. at 107 ("II]f [people] never acquired the habit of forming associations im ordinary life, civilization itself would be endangered.").

93. See 2 id. at $20-22$ (discussing low religion in the United States avails itself of democratic tendencies).

94. 2 id. at 22.

95. 2 id.

96. 2 id. at 121-28.

97. 1 id. at 305 . 


\section{Later Application of the Three-Sector Model: Developing the Idea of Civil Society}

De Tocqueville's analysis of the vital role played by voluntary associations in the United States was reformulated in a theoretical way by his contemporaries and recast in a slightly different form by successors. Hegel, for instance, distinguished between the state and civil society. He conceived of civil society as that segment of society which stood out froin the Prussian bureaucracy and included the diverse civic, fraternal, and religious associations that thrived in Germany durmg his time..$^{98}$ Hegel's concept of civil society was so broad that it included everything in society except the state, on one hand, and family life on the other. ${ }^{99}$

Jürgen Habermas also articulated a vision of a "public sphere" in society which is

diverse, divided into various subspheres or groupings constituted by niterests and expertise. It exists in close interaction with the state but is clearly not the state nor subordinate to the state. Above all, it is oriented toward open discussion of basic societal goals. It is not governed by the technical or, as he puts it, "instruinental rationality" that dominates both government bureaucracy and the capitalist inarketplace. ${ }^{100}$

More recently, the idea of civil society has provided the inspiration for the democratic reformers in Easteru Europe. ${ }^{101}$

Under this view, rooted in the three-sector model, ${ }^{102}$ civil society is the intermediary between the individual and the large, impersonal, and bureaucratic forces that govern many areas of life. ${ }^{103}$ It "naine[s] the space of uncoerced human association and also the set of relational networks-formed for the sake of family, faith, interest, and ideology - that fill this space." 104 Civil society is the place where people connect with

98. Wuthnow, supra note 12, at 11 (discussing G.W.F. HIEGEL, Philosophy of RIGHT (T.M. Knox trans., 1952) (1821)).

99. Id. at 11-12.

100. Id. at 12 (discussing JURgen Habermas, The STructural Transpormation of the Public Sphere (1962)).

101. See GeORGE KONRÁD, ANTIPolitics 176-243 (Richard E. Allen trans., 1984) (Hungarian dissident advancing civil society as an alternative to the state); see also JEFFREY C. GOLDFARB, THE CYN1CAL SOC1ETY (1991) (arguing that the hegemony of mass culture has made the United States a cynical society, where it is difficult to experience the human values necessary to sustain democracy).

Articulating the vision of civil society embraced by Hegel, Habermas, or one of these more modern commentators or contrasting these visions more comprehensively to de Tocqueville's is beyond the scope of this Comment. The important point here is the continued reiteration, most forcefully by de Tocqueville but also by others after him, of the vital and irreplaceable role played in democratic society by voluntary organizations-organizations that are concerned with the wellbeing of society but are independent of the state and the market.

102. WuTHNOW, supra note 12 , at 5-6.

103. Id. at 9-10.

104. Michael Walzer, The Idea of Civil Society: A Path to Social Reconstruction, DisSENT, Spring 1991, at 293 (advancing a notion of a civil society as the remedy to the disorder of 
others, form their behefs, and come to a knowledge of who they arewhere people truly live their lives. ${ }^{105}$

Because of its voluntary nature and its precarious position between two larger, more powerful sectors, the continued existence of civil society is always threatened by growth of those otler two sectors. ${ }^{106}$ Botli the state and the market are imperialistic in that they seek to bring imcreasingly large portions of society under their domains. In the Umited States, for example, the imperialism of the state is demonstrated by the expansion of bureaucracy since World War II. The government now assumes many functions that were once tlie domain of the private sector. ${ }^{107}$

Similarly, the imperialism of the market in the United States is demonstrated by a fundamental shift toward a service economy witl a highly professional work force and large, diversified, conglomerate corporations-toward a society whcre "only the professional elite has the cultural capital witl which to engage in effective discourse about public issues." 108 Indeed, the expansion of cost/benefit economic analysis to subjects sucli as the adoption of children demonstrates that even issues as intensely personal as family relations are no longer shielded from market

contemporary life); see also GREELEY, supra note 7, at 299 ("Catholic social theory . . . has a profound respect, one might say reverence, for the informal, the particular, the local, the familial.... [T]lis delicate and intricate web of primordial ties that bind human beings together in dense and close relationships [should not] be ignored or eliminated."). In another context, see Joseph Singer, The Player and the Cards: Nihilism and Legal Theory, 94 YALE L.J. 1, 70 (1984) ("The goal of politics and law should be to organize social life in a way that will maximize the number and variety of social situations in which contact among people is experienced as mutually self-validating and loving rather than mutually isolating and threatening.").

105. Although in the Umited States civil society is often referred to as the voluntary sector or the private sector, civil society is not private. It is an intensely public space where ideas are debated, values are discussed, commumities are formed, colleetive action is taken, and identities are shaped. The institutions that compose civil society-civic, religious, educational, and charitable groups-are all intensely imvolved in the community. The nature of these institutions demonstrates the inaccuracy of the label "private sector" and shows that the essence of civil society is public involvement with other members of the community. In fact, the very concept of civil society reflects a fact often lost sight of in common speech, namely, that society and the state are not identical. ... The care of the common good, therefore, must be understood as the concern not only of the state, but also of the entire array of subsidiary institutions and associations which form the social whole.

Gould, supra note 1, at 117-18.

106. [W] need to recognize above all that the third sector exists, as it were, at the mercy of the other two sectors.

$\cdots$

There is, in short, a very real danger of the bureaucratic welfare state and the advaneed institutions of planned corporate capitalism simply squeczing out the third sector, thereby robbing the society of a traditionally significant forum for public discourse about collective values.

Wuthnow, supra note 12, at 13-14; see also JACQUES MARITAIN, MAN AND THE STATE 22 (1951) ("[T]he state itself [should] launch a movement of progressive decentralization and 'destatization' of social life, tending toward the advent of some new personalist and pluralist regime."); WoLFE, supra note 67, at 13-19 (arguing that the state and the market are imperialistic and want to privatize the third sector with the result that society will be increasingly governed by large impersonal forces).

107. WuTHNow, supra note 12 , at 13.

108. Id. at 14 . 
influences. ${ }^{109}$ As the state and the market assume more power, they may threaten to eliminate altogether the ability of civil society to shape values, mores, and decisions. ${ }^{110}$

In the Umited States, the pressure on civil society is felt most acutely by religious groups. Religion is the leading force in American civil society ${ }^{111}$ and its institutional fate is linked with that of civil society. At the same time, lowever, rehigious institutions liave less access to government aid than do other groups in civil society. ${ }^{112}$

The Supreme Court should develop its Establishment Clause jurisprudence im light of this precarious position of civil society. Rehigion's well-being is crucial to the well-being of civil society im general. Religious associations teach people about tlie infinite worth of the individual, the obligation to tell the trutl, the importance of mutual respect, and the value of inutual care-all of the values that make other associations and, mdeed, deinocratic government possible. ${ }^{113}$ It is essential, therefore, that religion in particular and civil society in general flourish-not because religion is ultimately true, but rather because of its essential role in preserving deinocratic government.

Admittedly, religion is not the only place where citizens learu the values that inake democracy possible. These values can be learned through many institutions in civil society. ${ }^{114}$ It is possible to imagine an America witlout religion, where citizens still gamed an understanding of democracy througli otler voluntary groups. But this would be a hypothetical America. In reality, religion lias always played a prominent role

109. See Elizabeth Landes \& Richard Posner, The Economics of the Baby Shortage, 7 J. LEGAL STUD. 323, 324 (1978) (contending that "[a]doptions could in principle be handled through the market" and arguing for "a method of practical experimentation with introducing a market in adoptions"). But see Richard Posner, The Regulation of the Market in Adoptions, 67 B.U. L. REV. 59, 59-60 (1987) ("[A] profound misconception about the article [that I wrote with Elizabeth Landes] is that in discussing the pros and cons of using the inarket to equilibrate the demand for and snpply of babies for adoption, Dr. Landes and I were proposing a radical break with existing ethical norms.").

110. WuTHNow, supra note 12 , at 14 .

111. See supra text accompanying note 97.

112. WuTHNOW, supra note 12 , at 15-18.

113. It is in this sense that the church is public. See BELLAH ET AL., supra note 67:

[Public has come] to mean the citizenry who reflect on inatters of common concern, engage in deliberation together, and choose their representatives to constitute the government, whose powers are limited by a constitution. Religious bodies are very much part of this meaning of the public, not because they are governmentally "established" religions with legal privileges but because they enter into the common discussion about the public good. It is in this sense that one can legitimately speak of a "public church."

The founders of the American republic were quite clear on the public place of religion in this latter sense. They believed that religious belief made an essential contribution to the formation of a responsible citizenry capable of sustaining a democratic republic.

Id. at $179-80$.

114. Cf. John A. Coleman, AN American Strategic Theology 224-30 (1982) (arguing that religious freedom is inextricably linked with the freedom of other institutions in civil society). 
in American civil society, ${ }^{115}$ and it is profitless to pretend otherwise. The courts should recognize this reality in developing their Establishment Clause jurisprudence.

Under this conception of civil society, an expanding government can threaten religious liberty, and in turn, democracy, in two ways. First, whenever government engages in exphicitly rehgious activities it usurps rehgion's important functions. Second, when government performs an increasing number of functions traditionally reserved for the private sector and rehioious groups, it can displace rehgious institutions. This displaceinent is detrimental to religious institutions because those functions assumed by the government have traditionally been an important part of those institutions' identities. Both of these threats to rehgious liberty ultimately threaten denocracy because they expand its individualist, isolationist components and constrict the component of society where care and community are the guiding principles.

So this three-sector model suggests on the one hand that courts should be especially critical of government atteinpts to assume religion's role as a proponent of certain rehigious practices or behefs. On the other hand, courts should be especially willing to permit the government to compensate for its increasingly imperialistic encroachment on the private sector by aiding rehgion in its character-forming function. In order to give greater content to this suggestion, the next Section will articulate a more complete definition of civil religion.

\section{B. Developing the Values Essential to Civil Society: The Concept of Civil Religion}

Civil religion is the set of basic beliefs that a nation has about itself. ${ }^{116}$ It could just as easily be called civil mythology. It is not rehgion in the conventional sense at all; rather, it is secular and patriotic. For purposes of this discussion, conventional religion will be called "theological religion" and will be distinguished from civil rehion.

This distinction between civil religion and theological rehgion is the key to a more coherent, consistent approach to the Establishment Clause. Under this approach, the Estabhishment Clause does not apply at all to

115. See supra notes $4-10$ and accompanying text. Other scholars have focused on the importance of religion in the formation of group identity. See, e.g., GREELEY, supra note 8 (sociological study correlating Catholic behavior with Catholic sacramental theology); WiLL Herberg, Protestant-Catholic-Jew 23-35 (1955) (discussing the religious experience of recent immigrants to the United States); C. ERIC Lincoln \& Lawrence H. MamiYa, The Black CHURCH IN THE AFRICAN AMERICAN EXPERIENCE (1990) (historical and sociological survey of religion's role in African-American life); Charles E. Silberman, A Certain People: American Jews AND Their Lives Today (1985) (survey of American Jewish life).

116. John A. Coleman, Civil Religion, 31 Soc. ANALysis 67, 68 (1970) (arguing that civil religion is an essential concept for resolving debates about separation of church and state and the role of religion as integrator of society). 
government practices that facilitate or involve civil religion because such practices pose no threat to individuals' freedom to einbrace their own theologically religious behefs. So the preliminary question before the Court in each Establishment Clause case sliould be whether the questioned practice involves civil or theological rehigon. If it involves civil religion, it is permissible; if it involves public acknowledgment of or government support for theological religion, then it will be subject to Establishment Clause scrutiny and nay be impermissible. ${ }^{117}$

\section{The Origins and Definition of Civil Religion}

The modern notion of civil religion is rooted in Durkheim's pathbreaking study, The Elementary Forms of the Religious Life. ${ }^{118}$ Durkheim studied rehigion not merely from a theological or theoretical viewpoint, but ratler as an existing social reality. ${ }^{119} \mathrm{He}$ found that religion was not merely a private, individual phenomenon, but rather was something "eminently social."120

Durkheim discovered that "[r]ehgious representations are collective representations which express collective realities .... [T] hey are rich in social elennents." 121 These representations contain at least two elements: the sacred and the profane. ${ }^{122}$ The sacred, the realin of the good and the transcendent, is set apart froin the profane. ${ }^{123}$ Religion, therefore, is "a unified system of behefs and practices relative to sacred things, that is to

117. These theologically religious activities may be subjected to any one of the tests currently embraced by the Court or any other test that the Court deems appropriate. This Comment is agnostic about which, if any, of these tests should be adopted. It argues merely that none of these tests should be apphied to activities that are not theologically religious.

118. EMILE DURKheim, The Elementary FormS of THE Religious Life (Joseph W. Swain trans., 1915) (using archaic religion as a frame of reference to explore the origins of religion).

119. Durkheim argues:

[I]t is necessary to begin by freeing the mind of every preconceived idea. Men have becn obliged to make for themselves a notion of what religion is, long before the science of religions started its methodological comparisons. The necessities of existence force all of us, believers and non-behevers, to represent in some way these things in the midst of which we hive, upon which we must pass judgment constantly, and which we must take into account in all our conduct. However, since these preconceived ideals are formed without any method, according to the circumstances and chances of life, they have no right to any credit whatsoever, and must be rigorously set aside .... It is not from our prejudices, passions or habits that we should demand the elements of the definition which we nust Id. at 38 . have; it is from the reality itself which we are going to define.

120. Id. at 22 .

121. Id.

122. Id. at 52 .

123. Id. at 56. For further analysis of the distinction between the sacred and the profane, see Mircea Eliade, The Sacred and The Profane: The Nature of Religion (Willard R. Trask trans., 1959) (tracing manifestations of the sacred from primitive to modern times). Eliade draws on the work of RUDOLF OTTO, THE SACRED (1917), which analyzed religious experience principally in terms of its irrational aspects. ELIADE, supra, at 8. Eliade writes,

Otto sets himself to discover the characteristics of [the rehigious] experience [and finds it characterized by] the feeling of terror before the sacred, before the awe-inspiring mystery (mysterium tremendum), the majesty (majestas) that emanates an overwhelming 
say, things set apart and forbidden-beliefs and practices whicli unite into one single moral community called a Church, all those who adhere to tliem." 124 These beliefs about tlie sacred and the profane botll lielp to identify the collective and constitute it. ${ }^{125}$

According to this definition, tlien, rehgion is a mechanism for constructing meaning in the world. ${ }^{126}$ People are unable to accept meaninglessness. ${ }^{127}$ They are driven to make sense of the world around them. Any cultural system that "function[s] to syntliesize a people's ethos-the tone, character, and quality of their life, its moral and aesthetic style and mood-and their world view-the picture they liave of the way things in slieer actuality are," 128 is rehgious. Religion in this sense does not necessarily imply a deity-based behief structure. A systematic attempt to construct ineaning can be devoid of any conccpt of God but still be deeply and thoroughly rehigious. ${ }^{129}$

superiority of power [and a feeling of experiencing] something "wholly other" . . . something basically and totally different.

Id. at 9-10. Expanding on Otto's concept, Eliade includes the rational elements of religious experience to define the sacred and the profane as "two modes of being in the world." Id. at 14. A person hiving in the sacred mode always experiences "an other" greater than herself. Id. at 8-10.

124. Durkheim, supra note 118 , at 62 . Consistent with his endeavor, Durkheim was less concerned with defining what is sacred and what is profane than with noting that religions in fact make this distinction.

125. There is independent legal scholarship about the definition of religion. See, e.g., Jesse H. Choper, Defining "Religion" in the First Amendment, 1982 U. ILL. L. REV. 579, 612 (arguing that "what constitutes a 'rehigion' need be answered only in a very limited way for constitutional purposes"); George C. Freeman, III, The Misguided Search for the Constitutional Definition of "Religion," 71 GEO. L.J. 1519, 1565 (1983) ("[T]he search for the constitutional definition of "religion" is misguided. There simply is no essence of rehigion . ..."); Stanley Ingber, Religion or Ideology: A Needed Clarification of the Religion Clauses, 41 STAN. L. REV. 233, 240 (1989) ("[W]e can separate religion from ideology because of the role that a sacred or transcendental reality plays in imposing obligations upon the religious faithful."); Anand Agneshwar, Note, Rediscovering God in the Constitution: Defining Religion in the First Amendment, 67 N.Y.U. L. REV. 295 (1992) (arguing for a "transcendental reality" test); Note, Toward a Constitutional Definition of Religion, 91 HARV. L. REV. 1056, 1075 (1978) (advocating a functional, "ultimate coneerns" defimition for Free Exercise Clause cases but not for Establishment Clause cases).

126. Peter L. Berger, The Sacred Canopy: Elements of a Sociological Theory of RELIGION 25-28 (1967) ("Rehigion is the human enterprise by which a sacred cosmos is established." Id. at 25).

127. Id. at 56 ("Man cannot accept aloneness and he cannot accept meaninglessness."); see also JoHN SHEA, STORIES OF GOD: AN UNAUTHORIZED BIOGRAPHY 26, 39 (1978) (providing a theological account of the idea that faith is an attempt to explain mystery and avoid meaninglessness).

128. Clifford Geertz, The INTERPRetation of Cultures 89 (1973). Geertz defines religion as

(1) a system of symbols which acts to (2) establish powerful, pervasive, and long-lasting moods and motivations in men by (3) formulating conceptions of a general order of existence and (4) clothing these conceptions with such an aura of factuality that (5) the moods and motivations seem umiquely realistic.

Id. at 90 .

129. Every society is engaged in the never completed enterprise of building a humanly meaningful world. Cosmization implies the identification of this humanly meaningfnl world with the world as such .... Particularly in modern times there have been 
Religious beliefs in the sociological sense, then, are not held only by churches. They are held by many different groups and even by society as a whole. "For a society is not made up merely of the mass of individuals who compose it, the ground which they occupy, the things which they use and the movements which they perform, but above all is the idea which it forms of itself." 130

This view of cliaracter-forming beliefs about the ideal and the real prompted Durkheim himself to ask,

What essential difference is there between an assembly of Christians celebrating the principal dates of the life of Clirist, or of Jews remembering the exodus from Egypt or the promulgation of the decalogue, and a reumion of citizens commennorating the promulgation of a new inoral or legal system or soine great event in the national life? ${ }^{131}$

Durkheim's answer was that from a sociological viewpoint, all are deeply religious.

Civil rehigion, then, is nothing inore thian the set of shared representations and basic self-understandings of a society.

Civil Rehigion is a special case of the religious symbol system, designed to perform a differentiated function which is the umique province of neither church nor state. It is a set of symbolic forms and acts which relate man as citizen and his society in world listory to the ultimate conditions of his existence. ${ }^{132}$

\section{Civil Religion in America}

Civil rehigion in the United States is not only religious in the sociological definition just described, but it also contains elements of traditional rehion. The theologically religious elements in American civil rehigion complicate the analytic attempt to draw a distinction between theological religion and civil religion. ${ }^{133}$ In order to draw this distinc-

thoroughly secular attempts at cosmization, among which modern science is by far the most important.

BERGER, supra note 126, at 27; see also Coleman, supra note 116 , at $72-74$ (diseussing secular nationalism as a religious system). See generally ANDREW M. GREELEY, RELIGION: A SECULAR THEORY 9-10 (1982) (presenting a "secular" theory of religion grounded in the social sciences).

It might be argued that a conception of religion that is devoid of any notion of God is not plausible. But this response misses the point that the nature of the beliefs and the group experience are identical. Moreover, Durkheim's concept of religion merely provides the basis for understanding civil rehigion, which does not implicate First Amendment values. See infra text accompanying notes 164-71 (arguing that civil religion does not implicate First Amendment values).

130. DuRKheIM, supra note 118 , at 470 .

131. Id. at 475 .

132. Coleman, supra note 116 , at 69 .

133. See Note, supra note 29 , at $\mathbf{1 6 5 1 - 5 5}$ (discussing government use of religious symbols and practices in public life). 
tion, the nature of American civil rehigion inust be developed in nore detail.

The fabric of American civil rehigion is woven froin three threads: enlightenment rights theory, civic republicanisin, and the Bible. ${ }^{134}$ While both enlightenment rights theory and civic republicanisin liave sparked considerable recent interest in the legal acadenn, the biblical strand of our lieritage has been largely ignored. ${ }^{135}$ Still, froin tlie moment of John Winthrop's speecli aboard the Arabella, America lias always seen itself, in part, as a "city upon a hill," 136 beckonimg the rest of tlie world by the shimmering splendor of lier example. America has always been half-covenant as well as half-contract and we have liad a "historic[] commitınent . . . to both enlightenment and religion." "137

Consistent witl these three strands, the classic definition of "Civil Religion in America" is Robert Bellah's. ${ }^{138}$ Bellah contends that "certain common elennents of rehious orientation," sliared by the great inajority of Americans, "have played a crucial role in the development of American institutions and still provide a rehgious dimension for tlie whole fabric of American life, including the pohtical sphere."139 According to Bellah, there are four basic dogmas of this rehgious dimension: "the existence of God, the life to coine, the reward of virtue and the pumishment of vice, and tlie exclusion of religious intolerance."140

Public practices often einbody some of these dogmas in two ways that are especially relevant to Establishment Clause cases. First, the practices involve public acknowledgment of God's existence. Second, they einbrace a "theology" that America will only prosper to the extent tliat it is just.

134. See generally WiLliam L. MilleR, ThE FIRST LIBERTY: RELigion AND the AMERICAN REPUBLIC (1986) (historical account of the "securing" of America's religious liberty). Many successful reform movements in history have combined these three strands. The most recent example is the civil riglits movement of the 1960 s, led by Dr. Martin Luther King, Jr. See Antliony E. Cook, Beyond Critical Legal Studies: The Reconstructive Theology of Dr. Martin Luther King, Jr., 103 HARV. L. REV. 985, 988 (1990) (offering Dr. King's approacl as a blueprint for "reconstructing a just community").

135. See, e.g., Ronald Dworkin, Taking Rights Seriously (1977) (defining and defending a biberal theory of law based on individual liuman riglits); JUDITH JARVIS THOMSON, THE REALM of RIGHTS (1990) (dividing rights into two classes-those we liave by virtue of being human and those afforded by private interactions and law); Symposium: The Republican Civic Tradition, 97 YALE L.J. 1493 (1989).

136. Joseph R. Conlin, The Morrow Book of Quotations in AMERICA 323 (1984).

137. James H. Billington, Realism and Vision in American Foreign Policy, 65 ForeIGN AFFAIRS 630 (1986).

138. RoBERT N. BELlah, BEyond Belief 168-86 (1970) (arguing that civil religion has its own seriousness and integrity and requires the same care in understanding as any other religion does).

139. Id. at 171 .

140. Id. at 172 (borrowing from Jean-Jacques Rousseau, The Social Contract). 


\section{a. Public Acknowledgment of God}

Public acknowledgment of the existence of God has been part of American civil rehigion from the beginning. Every President has mentioned God in his inaugural address, although none has used sectarian references. ${ }^{141}$ In his first inaugural address, President Washington noted that "[i]t would be peculiarly improper to oumit in this first official act iny fervent supphications to that Almighty Being who rules over the umverse."142 President Adams addressed the "Being who is supreme over all." 143 Even Thomas Jefferson, who comed the phrase "wall of separation," 144 and is the patron saint of strict separationists, referred in his maugural address to "that Infinite Power which rules the destinies of the universe" and "that Being in whose hands we are."145

The tradition has contmued unbroken to this day. President John F. Kennedy made three references to God in his famous inaugural speech. ${ }^{146}$ Similarly, President Reagan referred continually to the deity while he was in office. ${ }^{147}$ Most recently, evangelist Bill Graham led a prayer at George Bush's and Bill Clinton's inaugurations. ${ }^{148}$

But public acknowledgment of God goes beyond inaugurations; it permeates public life. Every President, witl the exception of Jefferson, las promulgated Thanksgiving Day proclamations. ${ }^{149}$ Congress has always liad chaplains ${ }^{150}$ and we are now accustoned to the rituahistic Presidential benediction, "God Bless America."

Despite the nunierous references to and invocations of God, however, American civil religion has been renarkably free of sectarian references. ${ }^{151}$ The lack of sectariainsm is not because the Presidents were not themselves religious men. ${ }^{152}$ Ratlier, sectarian references were thought to lie outside tlie scope of civil religion and to violate one of its chief

141. Id. at 187 n.3.

142. Id. at 174 .

143. Id. at $187 \mathrm{n} .3$ (quoting Inaugural Addresses of the Presidents of THE UNITED States From GeORge Washington 1789 to HaRry S TRUMaN 1949, H.R. Doc. No. 540, 82d Cong., 2d Sess. (1952)).

144. CoRD, supra note 57, at 114 .

145. BellaH, supra note 138, at 187 n.3 (quoting INAUgural AdDRESSES of THE Presidents of the United States from George Washington 1789 to Harry S Truman 1949, H.R. Doc. No. 540, 82d Cong., 2d Sess. (1952)).

146. Id. at $168-69$.

147. See Richard V. Pierard \& Robert D. Linder, Civil Religion and the Presidency 257-83 (1988) (discussing civil religion during the Reagan presidency).

148. Haynes Johnson, Television and the Bush Inauguration: Made for Each Other, WAsH. PosT, Jan. 21, 1989, at A7; Walter Goodinan, In the Inaugural of Inclusion, All the Arts Are In, N.Y. TIMES, Jan. 21, 1992, at B3.

149. Robert Cord inakes clear, however, that Jefferson's reservations about Thanksgiving Day proclamations were not based on concerns about the Establishment Clause, but rather on concerns about trespassing on the legitimate province of states. CORD, supra note 57, at 40.

150. See infra Section VI.A.1.

151. BELLAH, supra note 138 , at 175 .

152. Id. at 175-76. 
principles-religious tolerance. ${ }^{153}$ The God acknowledged in civil religion's rituals is not the God of any traditional religion. Civil religion's prayers are not the prayers of any particular clrurcli. No doctrine of "traditional" religion is proinoted or offended by these invocations. The God of the civil religion is sui generis. As Bellah puts it:

Thougln inuch is selectively derived from Christianity, this religion is clearly not itself Christianity. . . . The God of the civil religion is not ouly rather "unitarian," he is also on the austere side, much more related to order, law, and right than to salvation and love. Even though he is soinewhat deist in cast, he is by no means simply a watchmaker God. ${ }^{154}$

\section{b. God's Unique Blessing of America}

The second aspect of civil rehigion that is perpetually repeated in the rituals of American public life is the behef that God lias uniquely blessed America and will assure its prosperity if it is virtuous. This elennentlike invocations of God-has been present since colonists first came to America and continues to this day. John Winthrop's speecli aboard the Arabella, in which he told the tiny group of travelers, essentially exiled froin their own country, "[T] he eyes of all people are upon us," 155 was perliaps the earliest articulation of the theine.

This belief in God's unique blessing is particularly prominent in the founders' imagery of the United States as a new Israel. When John Adauns, Benjamin Franklin, and Thounas Jefferson, designated by the Continental Congress, met to design a seal for the new nation,

Franklin proposed as the device Moses lifting up his wand and dividing the Red Sea while Pharaoll was overwhelmed by its waters, with the motto 'Rebellion to tyrants is obedience to God.' Jefferson proposed the children of Israel in the wilderness 'led by a cloud by day and a pillar of fire at night.'156

In his second inaugural, Jefferson continued this imagery of a new Israel. He acknowledged that he would "need ... the favor of that Being in whose liands we are, who led our fathers, as Israel of old, froin their native land and planted thein in a country flowing with all the necessaries and comforts of life."157

Abrahain Lincoln expanded the idea of America as a lioly place in the Gettysburg address when he spoke of the country already blessed by

153. Id. at 172; see also PIERARD \& LiNDER, supra note 147, at $30-32$ (recounting the misfortune of a fundamentalist minister who violated the tolerance aspect of civil religion by stating at a political prayer breakfast that "God Almighty does not hear the prayer of a Jew").

154. BeLLAH, supra note 138 , at 175 .

155. See Conlin, supra note 136, at 323 .

156. Bellah, supra note 138 , at 188 n.5 (quoting 1 ANSON P. STOKES, ChURCH AND STATE IN THE UNITED STATES 467-68 (1950)).

157. Id. at 175 . 
the blood of those Union nuartyrs "who here gave their lives, that that nation might live."158 More recently, Ronald Reagan revived Winthrop's vision of America as a city upon a hill. ${ }^{159}$ In fact, the seal of the United States still displays the inscription, in Latin, "God has favored our undertaking." 160

The shadow side of the behief that America is a chosen nation is the behief that the country will prosper only as long as it is virtuous. This aspect has also been present since the founding of the country. In his first inaugural address, President Washington remarked:

No people can be bound to acknowledge and adore the Invisible Hand which conducts the affairs of nuan more than those of the United States. Every step by which we have advanced to the character of an mdependent nation seens to have been distinguished by soine token of providential agency. ...

The propitious smiles of Heaven can never be expected on a nation that disregards the eternal rules of order and right which Heaven itself has ordained. ${ }^{161}$

Perhaps President Lyndon B. Johnson best articulated this elenient of American civil religion. In his maugural address, he spoke of the first settlers of this country, "the exile and the stranger, brave but frightened" who "miade a covenant with this land." Johnson believed that the covenant "binds us still," and added that "[i]f we keep its terms, we shall fiourish."162 Several inonths later, when he asked Congress for action on a voting rights bill, Johnson said:

For with a country as with a person, "What is a man profited, if he shall gain the whole world and lose his own soul?"

God will not favor everything that we do. It is rather our duty to divine his will. I cannot help but believe that $\mathrm{He}$ truly understands and that $\mathrm{He}$ really favors the undertaking that we begin here tonight. ${ }^{163}$

\section{c. Civil Religion's Differentiated Role in Society}

These two primcipal themes in American civil religion denionstrate the extent to which civil religion is independent of both the church and the state. ${ }^{164}$ Civil religion is independent of the church because its conception of God is umique and does not miatch that of any particular reli-

158. Id. at 178 .

159. PIERARD \& LiNDER, supra note 147, at 283.

160. Bellah, supra note 138 , at 181.

161. Id. at 174 .

162. Id. at 175 .

163. Id. at 181.

164. Coleman, supra note 116, at 74 ("In America we find almost a unique case of civil religion differentiated from both the church and state."). 
gious group. Moreover, civil religion is unconcerned with much of what preoccupies theological rehigion. Civil religion has no theology of the person, no view of creation, no eschatology, no ecclesiology, and no creed:

Civil religion does not even attempt to masquerade as a theological rehigion. ${ }^{165}$ In a pluralistic society, any sectarian civil rehigion would be unable to unite the society's diverse groups. ${ }^{166}$ Americans, with the notable exceptions of some small groups such as the Amish, embrace both the civil religion and involvement in more traditional churches, seeing, for the most part, no conflict between the two. ${ }^{167}$ This further demonstrates the fact that civil rehigion and theological rehion are coinpletely distinct entities.

Admittedly, civil religion is in some ways more consistent with the behefs of inany traditional churches than it is with the behefs of many nontraditional churches or with antireligious beliefs. This consistency is an inevitable outgrowth of the historical religiousness of the American

165. Richard John Neuhaus stated this well when he said:

Civil religion is not a [theological] religion. If it does not look like a duck, walk like a duck, or quack like a duck, the burden of proof rests with those who say it is a duck. After nineteen years of trying they have not made their case. . . . In short, only after we get past the question of whether civil religion is a [theological] religion can we address the important questious posed by the civil religion debate.

Richard J. Neuhaus, From Civil Religion to Public Philosophy, in Crvil Religion and PolmTICAL THEOLOGY 98, 102-03 (Leroy S. Rouner ed., 1986).

166. Coleman, supra note 116, at 74. In his seminal book, John Courtney Murray, S.J., argued that there is in fact a fundamental consensus on certain truths in American society-truths about the human person rooted in the Constitution. This consensus makes it possible, Murray argued, for many different religious groups to participate fully in American life. JOHN C. MURRAY, WE HOLD THESE TRUTHS 5-142 (1960); see also Gould, supra note 1.

Murray's thoughts are echoed in the basic rationale of The Declaration on Religious Freedom (Dignitatis Humanae) issued at Vatican II. Dignitatis Humanae proclaimed:

[T]lie human person has a right to religious freedom. This freedom ineans that all men are to be immune from coercion on the part of imdividuals or of social groups and of any human power, in such wise that in inatters religions no one is to be forced to act in a manner contrary to his own beliefs. Nor is anyone to be restrained froin acting in accordance with his own beliefs, whether privately or publicly, whether alone or in association witl others, within due limits.

....

... In all his activity a man is bound to follow his conscience faithfully, in order that he may come to God, for whom lie was created. It follows that he is not to be forced to act in a manner contrary to his conscience.

Renewing The Earth: Catholic Documents on Peace, Justice and Liberation 287, 295 (David J. O'Brien \& Thomas A. Sliannon eds., 1977). Dignitas Humanae inerely gives full voice to an old idea in Catholic teaching, the primaey of the individual conscience, that originated with Aquinas. Aquinas taught that people are bound to follow their conscience at all times, even if it is inistaken. Thomas Aquinas, PhILosophical TeXTS 291-92 (Thomas Gilby trans., 1982).

167. Coleman, supra note 116, at 74 ("[T]lie peculiar gervius of American civil religion is that it is not a substitute religion for the organized religions. It does not rob being a Catholic, Protestant, or Jew of specific ineaning."). The practices of the Amish are protected under the Free Exercise Clause. Wisconsin v. Yoder, 406 U.S. 205 (1972) (Amish children cannot be compelled to attend public high school). However, the nature of and rationale behind the proteetions are beyond the scope of this Comment. 
people. It is natural that the set of public beliefs that citizens have about their country will not be incompatible with beliefs they have about the world in general. Thus, while civil religion is fundamentally nontheological, it reflects a society whose very identity depends on some notions that happen to overlap witli traditional rehgion. Undermining these notions would actually undermine the identity of the entire society, whose members-including atheists-depend on these collective norms to remain connected with the whole.

American civil rehigion is also independent of the state because it represents more than blind nationalism. The America that is the center of civil religion's theology is the city upon a hill, an idealized version of the United States. ${ }^{168}$ Civil religion often involves unfavorable comparisons of the rcal nation with the ideal country. ${ }^{169}$ As illustrated by the many times that civil religion has been employed in protest, it is as inuch prophetic as patriotic and its messengers are as frequently Jeremialss as they are clieerleaders. ${ }^{170}$ Civil religion is not simply at the service of the state; iustead, it has an identity distinct from the state.

The sociological concept of civil rehigion illuminates the values involved in practices deeply rooted in American life. Civil rehigion is not theologically religious, despite the use of the word "God." It is mythic, patriotic, and secular. Thus, it does not threaten the religious biberty contemplated by the Establishment Clause.

\section{Giving Further Content to the Three-Sector Model: Activities that Are Essential to Civil Society}

The mere invocation of God, then, should not implicate the Establishment Clause at all. Nor sliould the reference to God as the protector of the United States. These images and references are not "religious" in the sense that the word is used in the Clause.

Similarly, the fact that an activity is undertaken by a theologically religious mstitution such as a church should not automatically invalidate government support for that activity. There are values that are uniquely promoted by civil society. In many cases, theologically religious groups are in a uniquely good position to promote these important values because religion is so prominent in civil society and because religion is particularly attentive to teaching many of the values that happen to be

168. BeLLAH, supra note 138, at 186 ("American civil religion is not the worship of the American nation but an understanding of the American experience in the light of ultimate and universal reality ...."); Coleman, supra note 116, at 75 ("It is not to the United States as it is but to what it should be and can becoine that the American civil religion looks.").

169. Coleman, supra note 116 , at 75.

170. The inost famous recent example is Dr. Martin Luther King, Jr. See Cook, supra note 134, at 1037 (noting King's attenpt to achieve "the secular equivalent of religious conversion"). 
important to civil society. ${ }^{171}$

In order to illuminate this idea, one must distinguish between the different types of activities that theologically rehigious groups perform. Some rehigious activities are specifically designed to shape a person's theologically rehigious beliefs. These activities usually include preaching, church services, spiritual counseling, and catechisin. These will be called "theologically rehigious" activities. Other activities are oriented toward shaping deinocratic values like community and mutual care rather than theologically rehigious behef. These activities include church charitable work, church schools, church liospitals, and church recreation centers. These will be called "civil society" activities.

These civil society activities, like many of the characteristics of civil religion, represent or promote values that are not inconsistent with theologically religious values. For example, inutual responsibility is an important part not only of civil society, but also of many theological rehgions. Similarly, the obligation to care for one's hiving ancestors contributes to the continuity of dennocracy and fulfills one of the Ten Commandinents.

To refuse to permit tlie government to help promote basic valueslike honesty, hard work, and mutual care - on which democracy depends merely because these values are also embraced by theological religions is hardly desirable. It is difficult to imagine how advocating honesty or hard work threatens any conventionally accepted notion of rehgious liberty. Indeed, such refusal is dangerous because it threatens the very social fabric that inakes American democracy, and therefore, American guarantees of rehigious liberty, possible.

The difficnlty, of course, is distinguishing between activities designed to proinote theological religion and those designed to proinote civil society values. This is an inquiry in which, to paraphrase Ohver Wendell Holmes, a drop of common sense will go farther than a gallon of logic. One way to assess the character of an activity is to look at the benefits it produces. ${ }^{172}$ Some activities inay produce benefits to civil society only if a person embraces the behefs of a theological religion. For example, a person inay be strengtliened by a worship service only if she accepts the belief of the religion that she is really worshipping God.

171. For some thoughts about religion's umique role in forming community, see JoHN A. Coleman, An American Strategic Theology (1982):

I simply do not know anywhere else to look in American culture besides to our religious etlical resources to find the social wisdom and ethical orientation we would seem to need if we are to face as Americans our new context of increasing interdependence at the national and international level.

Id. at 197-98; see also James S. Coleman \& Thomas Hoffer, Public and Private High SCHOOLS: THE IMPACT OF COMMUNITIES (1987) (arguing that the ability to build cominunity is what accounts for the fact that Catholic school students outperform public school students).

172. I am indebted to Professor Jesse Choper for this idea. See Jesse H. Choper, The Establishment Clause and Aid to Parochial Schools, 56 CALIF. L. REv. 260, 278-83 (1968). 
Activities that make the acceptance of a theologically religious belief or some other benefit to theological rehigion a necessary condition for the realization of a benefit to civil society can be called theologically religious activities.

Other types of activities undertaken by theologically religious groups produce benefits that do not necessarily depend on whether the beneficiary embraces theologically rehgious behiefs. For example, a patient being cared for in a religious hospital may benefit from the warmth and attentiveness of the medical care even if she does not embrace any theologically rehgious behef. When the benefits from a religious group's activities occur even if the group's behefs are not accepted, the activity can be called a civil religious, or civil society, activity.

\section{$\mathrm{V}$}

\section{INCOMPATIBILITY OF EXISTING ESTABLISHMENT CLAUSE TESTS WITH THE THREE-SECTOR MODEL AND THE ROLE OF CIVIL RELIGION}

The analytical fiaws of the three existing Establishment Clause tests have already been discussed. ${ }^{173}$ The tests are particularly undesirable because they are, as currently applied, incompatible with the framework for Establishment Clause adjudication suggested by the three-sector model and conception of civil religion presented here.

\section{A. The Lemon Test}

The Lemon test is particularly unattractive in light of the sociological analysis presented here. The Lemon decision has been responsible for what some commentators have termed the "privatization" of religion. ${ }^{174}$ The exercise of one of rehion's main functions, democratic education, will inevitably mvolve interaction between the government and religious groups that might properly be labeled "entanglement" or "advancement." 175 Analysis of this interaction under Lemon does not separate

173. See supra Part II.

174. See, e.g., Gerard V. Bradley, Dogmatomachy-A "Privatization" Theory of the Religion Clause Cases, 30 ST. Louts U. L.J. 275, $277-78$ (1986) ("[T] he cases since Everson . . . are most profitably understood as judicial attempts to move religion into the realm of subjective preference by eliminating religious consciousness. ... [T] here is little doubt that every current member of the Court subscribes to the privatization campaign ...."); Ricliard S. Meyers, The Supreme Court and the Privatization of Religion, 41 CATH. U. L. REV. 19 (199I); see also Lemon v. Kurtzman, 403 U.S. 602,625 (1971) ("The Constitution decrees that religion must be a private matter for the individual, the family, and the institutions of private clioice.").

175. Cf. Antliony J. Bevilacqua, Foreword: Church and State-Partners in Freedom, 39 DePaul L. Rev. 989 (1990):

From the very first step, it was the intent of botl the state and the church that they would walk the path not as strangers, and certainly not as enemies, but as friends in mutual support of each other. ... If cliurcl and state journeying together are to engage in friendly conversation, there cannot be a towering, inpregnable wall between them.

Id. at $989-91$. 
religion's important cliaracter-forming functions, which are vital to the state, and its particular sectarian purposes, which are of no concern to the state.

Thus, Lemon invalidates almost any program that involves government interaction with rehigion. Rehion has been effectively forced out of the public sector, creating the impression in many people that the Court is hostile to religion. The Lemon case and subsequent cases where the Court applied the Lemon test to invalidate direct government subsidies to religious schools demonstrate how Lemon lias reduced religion's public role. ${ }^{176}$ The Court determined that the subsidies botll advanced religion and fostered excessive entanglement. ${ }^{177}$ But these decisions did not consider the structural role of religion in society or the tremendous pressure that the clianging role of government placed on the private sector.

The Court's decisions on subsidies to religious private scliools took place agamst the backdrop of the greatest expansion in government in the history of the nation. Beginning with the New Deal and continuing through the Great Society, the federal government created a whole range of public health and welfare programs which assigned to the government a tremendous number of functions which had been traditionally exercised by the private sector. ${ }^{178}$ This government expansion shrank the scope of the private sector and limited the ability of civil society to provide participatory opportunities to citizens. The problem was both financial and functional. William Van Alstyne described the phenoinenon by pointing out:

To finance expanding government services . . . taxes may gradually divert an increasing fraction of total personal income, necessarily leaving proportionately less money in the private sector to each person to spend according to his individual choice, in support of religion or other undertakings. To the extent that the tax revenues thus collected may not be spent by government to support religious enterprises, but must be used exclusively for secular purposes, the net effect, argnably, is to reduce the relative supply of funds available to religion. ${ }^{179}$

As federal and state tax burdens have increased over the years, the groups and associations of civil society, which depend largely on private

176. See, e.g., Wolman v. Walter, 433 U.S. 229 (1977); Meek v. Pittenger, 421 U.S. 349 (1975); Committee for Pub. Educ. v. Nyquist, 413 U.S. 756 (1973); Levitt v. Committee for Pub. Educ., 413 U.S. 472 (1973); Lemon v. Kurtzman, 403 U.S. 602 (1971).

177. Lemon, 403 U.S. at 609.

178. See Daniel P. Moynihan, Social Justice in the Next Century, AMERICA, Sept. 14, 1991, at 132 (describing the new social problems, mcluding that of mass-scale dependence, occasioned by increased governmental activity).

179. William W. Van Alstyne, Constitutional Separation of Church and State: The Quest for a Coherent Position, 57 AM. PoL. SCI. REv. 865, 881 (1963) (footnote omitted). 
financial resources to survive, have suffered because there has been less money available for people to spend for any purpose, and civil society, therefore, has had fewer funds available. More importantly, since the government has assumed many activities that used to be performed by civil society, the scope of civil society's ability to make distinctive contributions to society has been restricted.

Even if Lemon did not create the impression of government hostility to religion and, instead, fulfilled its promise of strict neutrality toward religion, ${ }^{180}$ Lemon would still be undesirable. Given the imperialisin of the state and religion's role, in sociological terms, as a seedbed of virtue, the government should not be merely neutral toward religion's characterforming activities. Sucl neutrality effectively hinders rehigion from assuming its public role in the third sector. A deinocratic state should encourage these character-forming activities, which build the kinds of common values that make possible, legitimize, and strengthen that democratic state in the first place.

\section{B. The Endorsement Test}

The endorsement test is also undesirable for several reasons. First, because the test engages in an inquiry about the symbolic content of government action, it is hard to apply the test outside the public acknowledgment context in which it was originally articulated to situations where government action is not primarily comınunicative. For example, in Board of Education v. Mergens, ${ }^{181}$ the Court held that the Equal Access $\mathrm{Act}^{182}$ requires public schools that receive federal funding to allow religious clubs the same access to school facilities that they give nonreligious extracurricular student groups. ${ }^{183}$ In Mergens, such equal access included an opportunity to meet on school premises after school lours.

Different members of the Court, however, reaclied this decision for different reasons. Justice O'Connor, writing for a plurality of the Court, rejected petitioners' contention that the practice advanced rehigion. ${ }^{184}$

180. See School Dist. v. Schempp, 374 U.S. 203, 306 (I963) (Goldberg, J., concurring) ("It is said, and I agree, that the attitude of government toward religion must be one of neutrality."); see also BRUCE A. ACKerman, Social JUSTICE IN THE Liberal STATE 10-15 (1980) (arguing that the state ought to be neutral toward substantive visions of the good); Alan Schwarz, No Imposition of Religion: The Establishment Clause Value, 77 YALE L.J. 692 (1963) (advocating a principle siunilar to neutrality). But see LIBERALISM AND THE GOOD (R. Bruce Douglass et al. eds., 1990) (generally reviewing the issue of whether or not liberalism can be reconciled with substantivc visions of the good); Steven D. Smith, Symbols, Perceptions, and Doctrinal Illusions: Establishment Neutrality and the "No Endorsement" Test, 86 MICH. L. REv. 266, 325 (1987) (describing neutrality as "a parasitic concept").

181. 496 U.S. 226 (1990).

182. 20 U.S.C. $\$ \$ 4071-4074$ (1988).

183. Mergens, 496 U.S. at 246-47.

184. Id. at 249 (plurality opinion). 
She contended that allowing equal access to rehigious groups would not constitute an endorsement because an objective observer in the position of a secondary student would realize that the school was merely permitting the religious activity on an equal access basis. ${ }^{185}$ But Justice Kennedy disagreed with the plurality's application of an endorsement standard. He argued that it is

inevitable that a public high school "endorses" a rehigious club, in a common-sense use of the term, if the club happens to be one of Inany activities that the school permits students to choose in order to further the developinent of their intellect and character in an extracurricular setting. ${ }^{186}$

Thus, he concluded that endorseinent cannot function as the proper test. ${ }^{187}$ "The word endorsement has insufficient content to be dispositive. ... [I]ts hteral apphication may result in neutrality in name but hostility in fact." 188

The disagreement between Justice O'Connor and Justice Kennedy in Mergens illustrates the difficulties involved in applying the endorsement test. On the one hand, by allowing rehgious groups to ineet on school property, the school might appear to endorse those groups' existence, the fact that the groups have something positive to offer, and the idea that rehion is important enough to belong in school. Mergens illustrates the definitional difficulties involved in determining what constitutes an endorsement where the government engages in practices with no clear, agreed-on symbolic content.

A second problem with the endorsement test is that it potentially invalidates programs providing crucial support for rehgion's civil society activities. For example, the decision to fund private religious schools at all might be deemed an endorsement. The implicit message froin the government would be that it beheves that activities conducted by such schools are ineritorious enough to receive public funds. Even if the funding alone were not deemed an endorsement, the context in which it was given surely would be. It is impossible to imagine how the funding decision could ever be made without endorsing some activities undertaken by religious organizations. At some point, someone would have to state explicitly that the schools were being funded because rehigion promotes certain positive values which are essential to deinocracy. Presuinably, Justice O'Connor would consider this state action an endorsement because it would specifically acknowledge rehigion's miportant role in supporting the pohitical community.

The endorsenient test has, in fact, been apphed in just this way. In

185. Id. at 250 .

186. Id. at 261 (Kennedy, J., concurring in part and in the judgment).

187. Id.

188. Id. 
School District v. Ball, ${ }^{189}$ the Grand Rapids School District adopted and financed two separate programs for teaching classes in nonpublic schools: a shared-time program and a community education program. ${ }^{190}$ Both sets of classes were taught at nonpublic schools by public school employees. When teaching in a nonpubtic school classroom, the teachers were required to post a sign stating that the room was a public school classrooin. ${ }^{191}$ The shared-time program offered nonpublic school students remedial and enrichment classes in subjects such as reading, art, and inusic that were offered in the public schools. ${ }^{192}$ The shared-time teachers were full-time teachers, hired through the normal procedures, who moved from classrooin to classrooin throughout the school day, using supphies and inaterial paid for by the public schools. ${ }^{193}$

In addition, both children and adults could attend the conımunity education classes in activities such as Christnias Arts and Crafts, Honie Economics, Spamish, Yearbook, Drama, and Newspaper, also generally available in the pubtic schools. ${ }^{194}$ The classes began after the normal school day ended. ${ }^{195}$ The community education instructors were parttime employees of the school district and were nearly always full-time teachers at the nonpubtic school where they taught the conımunity education classes. 196

Relying on Lemon, the Court invalidated both the shared-time and the community education programs for three reasons. First, the Court worried that state-paid instructors miglit imdoctrinate students at state expense. ${ }^{197}$ Second, the Court feared that "[ $\left.t\right]$ he symbolic union of church and state" that arises from public school teacliers teaching classes in rehgious schools would "convey a inessage of state support for religion to students and to the general public."198 Finally, the Court beheved that the programs effectively subsidized the schools' sectarian instruction because they reinoved the schools' responsibility for large areas of "secular subjects." 199

Justice O'Co1mor concurred in the judgment in part and dissented in part. ${ }^{200}$ She agreed that the community education progran 1 violated the Estabhshinent Clause. "When full-time parochial school teachers receive public funds to teach secular courses to their parochial school

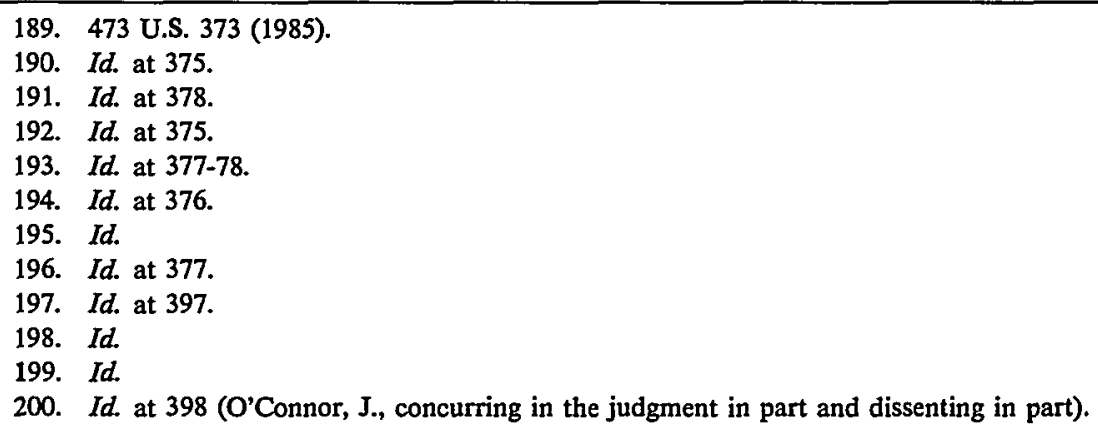


students under parochial school supervision, I agree that the program has the perceived and actual effect of advancing the rehigious aims of the church-related schools."201

This sentence makes clear that the endorsement test is incapable of distinguishing among different types of religious activities, the different effects that they have on society, and the different kinds of values that they promote. The type of funding involved in the shared-time program benefits rehigion in only a permissible, derivative way. At the same time, it substantially benefits society by furthering the ability of rehious schools to incnlcate the civil societal values so critical for the survival of deinocracy. Because the endorsement test would invalidate programs that are sociologically sensible, it is ill-suited to Establishınent Clause cases.

A third problem with the endorsenent test is its inconsistent apphcation. Justice O'Connor's decisions in other, closely related cases have been inconsistent with the rationale in Ball. In Ball, she upheld the shared-time program based on her conviction that the professionalism of public school teachers would stop thein from either using or appearing to use their positions for rehigious indoctrination. ${ }^{202}$ For similar reasons, Justice O'Connor dissented in Aguilar v. Felton. ${ }^{203}$ In that case, the Court invalidated a New York City program that used Title I funds to aid educationally-deprived children by employing full-time public school teachers who volunteered to teach reinedial reading, writing, and mathematics in the parochial schools. Again, Justice O'Connor did not believe that there was any reason to fear indoctrination or the advanceinent or endorseinent of rehigion by these professional educators. ${ }^{204}$

But under the endorseinent test, the harm of this type of program is logically the same as that of the commurity education program. In both prograins, the state accepts the parochial school as a legitimate educational forum and offers financial resources, supphes, and persoimel to help it better educate its students. Justice O'Connor never explamed why the identity of the person hired should change the "statement" that the government makes. There is no convincing way to distinguish these situations for Estabhshinent Clause purposes.

Indeed, it is unclear whether O'Connor herself truly accepts the logic of her decision in Ball. In Bowen v. Kendrick ${ }^{205}$ Justice O'Connor concurred in the Court's decision to uphold certain provisions of the Adolescent Farnily Lifc Act. ${ }^{206}$ That Act allowed federal government

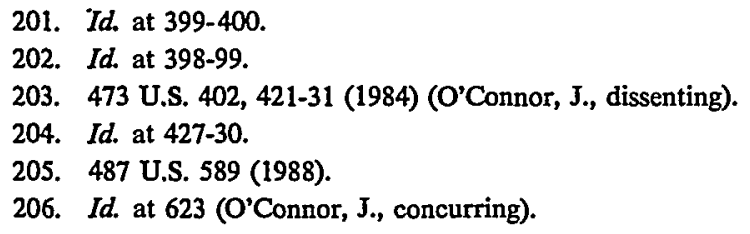


funds designated to address the problem of adolescent pregnancy to flow to religious institutions that had programs to address this problem. ${ }^{207}$ In her concurrence, Justice O'Connor noted, "Using religious organizations to advance the secular goals of the AFLA, without thereby permitting religious indoctrination, is inevitably more difficult than in other projects, such as ministering to the poor and the sick."208 That statement is indisputable. Despite these difficulties, however, the Court did permit religious institutions to receive AFLA funds.

There is no logical difference nnder the endorseinent test between a teenage pregnancy counseling center run by a churcli and a church school. Giving government money to either institution potentially amounts to the government funding religious belief. The distinction drawn by the Court is that pregnancy centers, unlike schools, are not "pervasively sectarian." 209 However, it is hard to see low a Catholic-run center counseling a young woman about her nnwanted pregnancy is not likely to be inore pervasively sectarian than a geography class at a Catholic schiool. ${ }^{210}$

The "pervasively sectarian" standard, then, cannot distinguish among a rehigious school's different activities. Many of these activities are not imtended to affect theologically religious belief, and it ought to be permissible to fund them. Funding abuses, as the Bowen court noted, can always be addressed as they occur.

The endorsement test, then, is sociologically unsound. When applied to all types of Establishment Clause cliallenges, the test may invalidate government support for activities that are not theologically religious but that lappen to be perforned by rehigious groups. In so doing, the test could himder religious groups from proinoting certain values that are not theolgically religious and deny civil society the benefit of these values.

207. 487 U.S. at 596.

208. Id. at 623 (O'Connor, J., concurring).

209. 487 U.S. at 621

210. See, e.g., Michael W. McConnell, Political and Religious Disestablishment, 1986 B.Y.U. L. REV. 405:

[An] ... argument for treating parochial school aid with more exacting scrutiny rests on the assumption that education involves religious indoctrination but other social welfare functions do not. However, many, if not most, churches understand their ministry to physical needs as integrally related to their mission of spreading the gospel. Who can doubt that the Salvation Army puts a message into each cup of coffee? Indeed, to the extent that parochial schools are selected predominantly by persons who are already members of the schools' religious group, while most social welfare programs are targeted to the public at large, proselytizing is more likely in the latter than the former.

Id. at 422-23 (citation omitted). 


\section{The Coercion Test}

Under the coercion test, government practices are permissible if they do not coerce anyone to beheve in a religion. ${ }^{211}$ The coercion test is unore likely than either the Lemon test or the endorsement test to yield results that are consistent with the Tocquevillian perspective advocated here. Language in Justice Kennedy's opinion in County of Allegheny v. $A C L U^{212}$ shows a remarkable sensitivity to the fragility of civil society and awareness of the strains that state expansion has placed on it. The coercion test allows government to recognize and even to "endorse" rehgion's public role but prohibits government froin threatening the autonomy of rehgious institutions or the conscience of the individual.

An example of how the coercion test might be applied can be seen in Justice Kennedy's concurring opinion in Bowen v. Kendrick. ${ }^{213}$ Kennedy agreed with the Court's judgment that religious organizations could be involved in AFLA programs. He wrote separately, however, to cominent on the part of the Court's opinion that invited "appellees on remand to show that AFLA aid is flowing to grantees that can be considered 'pervasively sectarian' rehigious institutions."214 Kennedy argued that since the Court had upheld a statute that apphed neutrally to a range of diverse groups, it would not be enough to show that a pervasively sectarian institution had received funds. ${ }^{215}$ Instead, Kennedy beheved that the appropriate issue was whether the funds were in fact used to advance religion. ${ }^{216}$

This outcoine and line of reasoning are conipatible with the sociological analysis presented here. The Court should allow government funds to support religion's civil society activities but not its theologically religious activities. Rather than sinuply prohibiting rehigious groups from receiving government funds, the Bowen Court recognized that it was appropriate to allow religious groups to receive federal funds to the extent that they used those funds to proniote public purposes and democratic values and not specific theologically rehigious beliefs.

Even the coercion test, however, has two principal problems. First, as currently articulated by Justice Kennedy, the coercion test might strike down government activities that are not theologically rehigious at all. For example, it nright invalidate a government practice that was deemed to "coerce" behef in values einbodied in civil religion. ${ }^{217}$ But

211. See County of Allegheny v. ACLU, 492 U.S. 573, 662 (1989) (Kennedy, J., concurring in the judgment in part and dissenting in part) ("Absent coercion, the risk of infringenent of religious liberty ... is minimal.").

212. Id. at 655 .

213. 487 U.S. 589, 624 (1988) (Kennedy, J., concurring).

214. Id.

215. Id.

216. Id. at $624-25$.

217. See infra Section VI.A.2 (discussing the Supreme Court's recent decision in Lee v. 
civil rehigion should be exempt from the Establishment Clause altogether.

Second, the coercion test might allow the government to engage in exphicitly theologically religious practices as long as those practices were noncoercive. Thus, in Allegheny, Justice Kemiedy used the test to justify the crèche displays. ${ }^{218}$ But under the sociological analysis presented here, such displays may be impermissible if they result in the government trespassimg on rehigion's autonony.

Similarly, the coercion test might justify aid to the belief activities of churches as long as the aid was minimal and the churches' activities were noncoercive. This outcome is also troubling from the perspective advocated here. While the coercion test most nearly approximates an outcome desirable in hight of the three-sector nodel, it is clear that a new test is needed.

VI

\section{The Three-Sector Model Applied to CASes}

\section{A. Public Acknowledgment of Religion}

In a confusing and contradictory series of cases, the Court has tried to decide what types of public acknowledgments of God are constitutionally permissible. Public acknowledgment cases involve practices such as legislative prayer, ${ }^{219}$ prayer at school graduations, ${ }^{220}$ and the display of religious symbols on public property. ${ }^{221}$ The Court has struggled inightily in these cases, but lias not consistently applied any single principle to them. ${ }^{222}$

Instead, the Court lias applied a vague concept, whicli it labels "cereinonial deism," to justify some of the practices with which it has been confronted. ${ }^{223}$ But the Court has never really defined ceremonial deism. The term seems to be simply shorthand for the Court's judgment that a practice ought to be permissible because it is not really religious-that it

Weisman, which invalidated a benediction at a public school graduation because of the benediction's perceived indirectly coercive effects on the children).

218. See infra Section VI.A.4.

219. See, e.g., Marsh v. Chambers, 463 U.S. 783 (1983) (upholding a state legislature's use of prayer in opening its legislative session).

220. See, e.g., Lee v. Weisinan, 112 S. Ct. 2649 (1992) (holding that a benediction invoking the deity, dehivered by a clergyman at an annual public school graduation, violated the Establishment Clause).

221. See, e.g., County of Allegheny v. ACLU, 492 U.S. 573, $592-97$ (1989) (finding that the city's crèche display violated the Establishment Clause).

222. See, e.g., id. (using elements of both the Lemon and endorsement tests); Marsh, 463 U.S. at 796-97 (Brennan, J., dissenting) (disapproving of the majority's failure to apply the Lemon test).

223. See Allegheny, 492 U.S. at $595 \mathrm{n} .46$ (the function of ceremonial deism suggests that its practices are not understood as conveying government approval of particular religious beliefs); Lynch v. Donnelly, 465 U.S. 668, 716 (1984) (Brennan, J., dissenting) (arguing that ceremonial deisun does not violate the Establishınent Clause because activities representing ceremonial deism have lost, through repetition, any religious content). 
has lost the rehigious significance it once had ${ }^{224}$ or it is now used only to solemnize a public occasion. Because the concept itself is so vague and undefined, decisions employing this concept are inconsistent with each other. ${ }^{225}$

Civil religion, with its identification of the symbols and themes that compose national self-identity, is an appropriate replacement for the concept of "ceremonial deism." Where the Court has analyzed Establishment Clause problems under the rubric of ceremonial deism, the Court's initial intuition was often correct: inany of the practices involved did not threaten First Amendment values and should have been permissible.

Beyond this intuition, however, the Court's reasoning was unsatisfactory because the Court failed to recognize that ceremonial deism cases really involve public acknowledgments of civil religion. Civil religion, with its concern about the kinds of iniages and values by which our society defines itself, does not threaten any traditional religion. Furtliermore, one of its basic tenets is that rehgious diversity is iniportant. Rites of civil religion pose no threat to the central First Amendment value of religious liberty. Applying the civil religion concept to some public acknowledgment cases illustrates low the concept miglit work im adjudication.

\section{Marsli v. Chainbers ${ }^{226}$}

In Marsh v. Chambers, Ernest Chambers, a member of the Nebraska Legislature, challenged the Legislature's practice of opening eacli session with a prayer. The prayer was delivered by a cliaplain who was paid with state funds. In a six-to-three decision, the Court upheld the practice. 227

Writing for the majority, Chief Justice Burger gave three reasons for the decision. First, there was an "unambiguous and unbroken listory of unore than 200 years . . . of opening legislative sessions with prayer."228 "To invoke Divine guidance on a public body entrusted witl making tlie laws is not, in these circunistances, an 'establishment' of rehigion or a step toward establishment; it is siniply a tolerable acknowledgment of beliefs widely lield among the people of this country."229 Second, just three days before it approved the Bill of Riglits, the First Congress passed a statute providing for the payment of clraplains for both the House and the Senate. ${ }^{230}$ Finally, there was no evidence in the record that the

224. Lynch, 465 U.S. at 716 (Brennan, J., dissenting).

225. See infra Sections VI.A.1-4.

226. 463 U.S. 783 (1983).

227. Id. at 795 .

228. Id. at 792 .

229. Id.

230. Id. at 788 . 
prayer privilege was ever abused or that any chaplain used the occasion to proselytize. ${ }^{231}$

The majority's argument in Marsh amounts to nothing more than the assertion that, "The founders did it. Everyone since them has done it. No one is abusing it. Therefore it is constitutional." This is hardly a convincing constitutional argument. Although the Court was coincidentally correct when it called the prayers "tolerable acknowledgment[s] of beliefs widely held among the people of this country,"232 the Court failed to justify this assertion.

Instead of utilizing a confusing historical analysis, the Court should have recognized that the Marsh prayers do not violate the First Amendment because they do not involve theological religion at all. Instead, they exeinplify American civil religion. Indeed, the Marsh prayers include both main themes of American civil religion: public acknowledgment of God and the behef that the nation will prosper if it follows that guidance.

Ironically, the Court noted in footnote fourteen that the legislative chaplain in Nebraska characterized his prayers as "'nonsectarian," witl " "elements of the American civil religion." "233 The Court did not seize on this distinction, however, because of its reluctance to scrutinize the content of the prayer. ${ }^{234}$ This reluctance was misguided. A court inust always scrutinize the content of a public prayer, at least to the degree necessary to determine if it is sectarian or used for proselytization. ${ }^{235}$ Once it is clear that a prayer involves only civil religion, no further scrutiny is needed.

\section{Lee v. Weisman ${ }^{236}$}

The Marsh inajority's historical analysis initiated a lively debate about the true nieaning of Marsh and attenipts to limit the scope of that case's liolding. The Marsh debate centers around a two-part question: should otler traditional forms of public prayer be exempt from First Amendment scrutiny or is Marsh's historical analysis unique to legislative prayer because tliat analysis focused only on the founders' approval of legislative prayer? ?37

This tension gave rise to a very important case recently decided by the Court-Lee v. Weisman. Deborall Weisnian attended Nathan Bishop Middle Scliool in Providence, Rhode Island. Four days before lier graduation, her father, Dainel Weisman, filed a complaint in federal

231. Id. at 794-95.

232. Id. at 792 .

233. Id. at $793 \mathrm{n} .14$.

234. Id. at 794-95.

235. See $i d$. for the Court's scrutiny of the prayer in Marsh.

236. 112 S. Ct. 2649 (1992).

237. See id. at 2660 (distinguishing the facts of Marsh from the facts of Weisman). 
court asking that the school district be enjoined from including any prayers in the graduation ceremony.

The district judge denied the motion, contending that there was insufficient time before the cereniony to address adequately the issues involved. ${ }^{238}$ The graduation went forward as planned. At the cereniony, Rabbi Leshe Gutterman delivered botli an invocation and a benediction. In the invocation, he prayed:

God of the Free, Hope of the Brave:

For the legacy of America where diversity is celebrated and the rights of minorities are protected, we thank You. May these young men and women grow up to enrich it.

For the liberty of America, we thank You. May these new graduates grow up to guard it.

For the political process of America in which all its citizens may participate, for its court system where all may seek justice we thank You. May those we honor this morning always turn to it in trust.

For the destiny of America we thank You. May the graduates of Nathan Bishop Middle School so hive that they might help to share it.

May our aspirations for our country and for these young people, who are our hope for the future, be richly fulfilled.

AMEN. ${ }^{239}$

Rabbi Gutterman's prayer represents a classic example of civil rehgion. ${ }^{240}$ The opening reference to God was neither specifically Jewish nor broadly biblical. Instead, the God described resembles much more closely the "God" of civil religion described by Bellah. ${ }^{241}$ God was characterized in umquely American terms taken from the national anthein.

The prayer also contained other elements of American civil rehion. It recognized the "legacy" of America and gave thanks for the unique destiny of America- a behef found in civil rehgion but not in traditional theology. ${ }^{242}$ It invoked God's providence when it asked that the graduates, "our liope for the future," live to share the nation's heritage. Finally, the prayer gave thanks for minority rights in America and

238. Id. at 2654 .

239. Id. at 2652-53.

240. In fact, Weisman's attorney conceded as much to the trial court when she admitted that the only part of the prayer which offended her client, an atheist Jew, was the mention of the word God. See Joint Appendix to Parties' Supreme Court Briefs at 29, Lee v. Weisman, 112 S. Ct. 2649 (1992) (No. 90-1014).

241. See supra notes $138-40$ and accompanying text.

242. Most of the major religious traditions see God as universal and have no specific beliefs about America or any other nation. The notable exception is Judaism. But acceptance of Zionism as au integral part of Judaism, of course, does not explain belief iu American exceptionalism. 
praised the nation's diversity, including its religious diversity. ${ }^{243}$ Under the sociological analysis advocated here, the prayer sliould have been permitted because it was not theologically religious.

But the Supreme Court disagreed. In a five-to-four decision, the Court held tliat Rabbi Gutterman's prayer was unconstitutional because it coerced students to pray. ${ }^{244}$ Writing for the Court, Justice Kennedy rehed on and developed the coercion test he had first articulated in Allegheny.

In developing this test, Kennedy discussed coercion in largely psychological terms. He expressed the fear that a graduating student would feel such peer pressure from her fellow graduates tliat she might feel she had no choice but to stand and participate in the prayer if she attended graduation. ${ }^{245}$ To Kennedy, this pressure is unacceptable because it puts the government, actimg through school officials, in the position of forcmg students to pray. ${ }^{246}$ Kennedy also rejected petitioner's argument that no coercion occurred because the graduation ceremony itself was not mandatory. ${ }^{247}$ To Kennedy, the importance of the ceremony in the student's life made that argument untenable. ${ }^{248}$

Justices Blackmun, Stevens, O'Connor, and Souter concurred with Justice Keunedy's conclusion that the prayers were coercive and that the coercion was enough to render the prayers unconstitutional. ${ }^{249}$ But the concurring Justices specifically disagreed with Kennedy's position that coercion is the proper ineasure of an Establishment Clause violation. ${ }^{250}$ Instead, they embraced Justice O'Connor's endorsement test, which has never mustered a majority of the Court. ${ }^{251}$

Chief Justice Rehnquist and Justices White, Scalia, and Thomas dissented. They embraced Justice Kennedy's coercion test but disagreed with him about the test's real meaning and its apphication to the facts of the Weisman case. ${ }^{252}$ Justice Scalia's opinion criticized what lie believed to be the Court's invention of "a boundless, and boundlessly manipulable, test of psychological coercion." "253 His criticism was really twofold. On a practical level, he argued that if the students were coerced at all, it was inerely to sit or stand in respectful silence-not to pray-and tliat this silence is a basic element of democratic civility rather than an

243. It seems fair to infer praise for religious diversity from Rabbi Gutterman's presence at the ceremony.

244. Weisman, $112 \mathrm{~S}$. Ct. at 2658.

245. Id.

246. Id. at 2657-58.

247. Id. at 2659.

248. Id.

249. Id. at 2664 (Blackmun, J., concurring); Id. at 2667 (Souter, J., concurring).

250. Id. at 2664 (Blackmun, J., concurring); Id. at 2673 (Souter, J., concurring).

251. Here, for example, only four members of the Court embraced the endorsement test.

252. Id. at 2681-82, 2684 (Scalia, J., dissenting).

253. Id. at 2679. 
infringement of religious liberty. ${ }^{254}$ On a more theoretical level, Scalia argued that the only sensible definition of coercion is "coercion of religious orthodoxy and of financial support by force of law and threat of penalty."25s Since neither force of law nor threat of penalty forced the students in this case to stand, Scalia contended that there was no violation..$^{256}$

Unfortunately, instead of producing a consistent approacl to the Establishment Clause, the case produced four opinions with different approaches to the Clause. But a more surprising aspect of the decision is that it seemed to ignore inucli of the force of Lemon. ${ }^{257}$ The Court did refer to Lemon in order to refuse the petitioner's invitation to reconsider the decision. ${ }^{258}$ But it procecded to decide the case on a coercion-based theory without indicating how that theory fits into the Lemon framework and whether that theory now governs Establishment Clause jurisprudence. Thus, it remains unclear after Weisman what legal test actually controls Establishment Clause claims.

The dispute between the Justices in this case seems to be over the existence and meaning of historical practices in this area and over the effect that public acknowledgments have on unwilling participants. Ironically, although the concept of civil religion presented in this Comment lelps to resolve this dispute, Justice Kennedy's opinion seems to reject the concept as a guide to decisionmaking:

There may be some support, as an empirical observation, to the statement ... that there lias emerged in this country a civic religion, one which is tolerated when sectarian exercises are not. If common ground can be defined which permits once conflicting faiths to express the shared conviction that there is an ethic and a morality which transcend human invention, the sense of commumity and purpose souglit by all decent societies inight be advanced. But though the First Amendment does not allow the government to stifle prayers which aspire to these ends, neither does it permit the government to undertake that task for itself.

...

... [Our] precedents caution us to measure the idea of a civic religion against the central meaning of the Rehigion Clauses of the First Amendment, which is that all creeds must be tolerated and none favored. The suggestion that government may establish an official or civic rehigion as a means of avoiding the establishment of a religion with more specific creeds strikes us as a contradiction

254. Id. at 2682 .

255. Id. at 2683.

256. Id. at 2682-83.

257. See 112 S. Ct. at 2655.

258. Id. 
that cannot be accepted. 259

Kennedy's rejection of civil religion is based on twin misunderstandings. He fails to understand both civil religion itself and its relation to the state. In his description of civil religion, Kennedy sets up a straw man. He places civil religion "within the embrace of what is known as the Judeo-Christian tradition" and speculates that its broad nonsectarianism might make it inore acceptable than more specifically sectarian prayer. ${ }^{260}$

Kennedy's "civic religion" is really nothing more than a bland nonsectariamism-prayer directed "to whom it may concern" and stripped of many offensive elements. But civil religion is more than inere nonsectarianism; rather, it is a distimct and identifiable set of beliefs, contmuously present througliout American history. It concerns the United States, its identity, and its role in the world. Civil religion is not within the JudeoChristian heritage-or any theologically religious heritage in particular. It is a concept functionally independent of those theological beliefs even though some of the content of civil religion necessarily overlaps with some of the theologically rehigious behefs by which a society might assess its collective identity.

Kennedy misrepresents civil religion in a second way. He seems concerned that the government will use civil religion to prescribe or proscribe religious belief. ${ }^{261}$ This concern is unfounded, however, because civil religion is not merely an instrument of the state. Rather, it is deeply rooted in the American identity mytl, and its tenets can be turned againist the state as easily as they can be in favor of the state. Furthermore, even if the state could manipulate civil religion as a kind of blind Americamism, the state would merely be promoting patriotism and other values central to democracy. It is difficult to argue that the First Amendment prohibits fostering these pro-democratic values that are essential to the strength of the democratic system.

\section{Stein v. Plainwell Community Schools ${ }^{262}$}

Notwithstanding Justice Kennedy's unconvincing assertions, civil religion can be used effectively as an adjudicative tool. One court has already applied the concept of civil religion in an attenipt to make sense

259. Id. at $2656-57$ (citations omitted).

260. Id. at 2656 .

261. Id. at 2657. In addition to not addressing the civil religion question convincingly, Kennedy also failed to address the question of how Rabbi Guttermann served as a state actor. Kennedy asserted that the school district composed the prayers, but the record shows only that it provided the Rabbi with guidelines. Kennedy equated the two without saying why they are the same for constitutional purposes.

262. 822 F.2d 1406 (6th Cir. 1987). For a more detailed discussion of the way that civil religion was used in the case, see Linn Van Meter-Drew, Comment, Stein v. Plainwell Community SchoolsThe American Civil Religion and the Establishment Clause, 15 HAstings CoNST. L.Q. 533 (1988). 
of ceremomial deism. In Stein v. Plainwell Community Schools, the court examined the constitutionality of benedictions and invocations at public scliool graduations. The prayers at issue were diverse. Some were nonsectarian, mcluded quotations from Kahlil Gibran and Francis of Assisi, and gave general thanks for "the inany gifts [God lras] given us [including] ... the gifts of knowledge, love, and freedom."263 Other prayers, lowever, were sectarian and mentioned "Christ our Lord."264

Although these prayers occurred at a public school graduation, the court used the ceremomial prayer analysis developed in Marsh to evaluate them. Attemptimg to explain the type of prayers that are permissible under Marsh, the court concluded that ceremomial prayer can be defined as " 'civil' or secularized ... . [prayer that] does not go beyond 'tlie American civil rehgion." "265 The Sixth Circuit panel did not develop exactly what it meant by civil religion. But the concept seemed to include prayers that were nonsectarian and primiarily ceremonial. ${ }^{266}$ The court concluded that the graduation prayers at issue in Stein violated the Establishment Clause because they included specific Christian references and "symbohically place[d] the government's seal of approval on ... the Christian view."267

Althougl Kennedy's majority opinion in Weisman rejected the Stein analysis, Stein surely shows that the concept of civil religion can be more helpful than a vague notion of psycliological coercion that mustered only one vote on the Court. Prayers involving secular ideas derived from civil religion ought to be permissible, whereas prayers derived from theologically rehigious ideas should be more closely scrutinized. The more accurate and nuanced version of civil religion presented in this Comment, rather than the caricature rejected by Justice Kennedy, would niake it possible for Courts to apply the idea im a more coherent and systematic way.

\section{Civil Religion Misapplied: The Crèche Cases}

The differences between the concept of civil rehgion articulated here and the Supreme Court's conception of ceremonial deism are illustrated in the crèche cases. These differences reveal that the crèche cases were, in light of the sociological analysis suggested here, wrongly decided. The two most famous of these cases are Lynch v. Donnelly ${ }^{268}$ and County of Allegheny v. ACLU. ${ }^{269}$

In Lynch, the Court, by a narrow five-to-four vote, upheld the con-

\footnotetext{
263. Stein, 822 F.2d at 1407 n.1.

264. Id. at 1407 n.2.

265. Id. at 1409 .

266. Id. at 1409-10.

267. Id. at 1410 .

268. 465 U.S. 668 (1984).

269. 492 U.S. 573 (1989).
} 
stitutionality of a Christmas display erected by the city of Pawtucket, Rhode Island. The display consisted of a Santa Claus house, remdeer, a Christmas tree, candy-striped poles, carolers, colored lights, a large "Seasons Greetings" banner, and a crèche. Relying on Lemon, the Court held that the practice did not violate the Establishment Clause. 270

A key issue in the case was whether the nativity display violated the second prong of Lemon by advancing religion. The inajority opinion coinpared the level of advancement involved in displaying a nativity scene with a long hist of acceptable instances of ceremomal deisin and permissible government support of rehion. ${ }^{271}$ The Court then concluded that the display of the nativity scene was permissible because it advanced religion far less than inany things already declared constitutional. 272

Justice O'Connor apphied the endorsement test and reached a similar result. She concluded that the crèche, like other symbols of ceremonial deism, did not endorse religion but served "in the only ways reasonably possible in our culture, the legitimate secular purposes of solemnizing public occasions, expressing confidence in the future, and encouraging the recognition of what is worthy of appreciation in society."273

Justice Brennan dissented. He agreed that the instances of cereinonial deism were not unconstitutional, but based this conclusion on his behief that "they have lost through rote repetition any significant religious content" and are not acknowledgments of religion in any way. ${ }^{274}$

A few years later, in County of Allegheny v. $A C L U,{ }^{275}$ the Court agaim addressed the crèche issue. In Allegheny, the Court invalidated the display of a crèche that was surrounded only by flowers and located at the foot of the main staircase in the county government building. ${ }^{276} \mathrm{But}$ the Court upheld the display of an eighteen-foot menorali in front of the building. ${ }^{277}$

The Court drew a distinction between the two displays because the menorali was positioned next to a forty-five-foot Christmas tree and a sign saluting liberty. ${ }^{278}$ Writing for the majority, Justice Blackmun concluded that while the nativity scene was undeniably religious, the menorah was not because it was positioned next to a Christmas tree. Overall, then, the display "simply recognize[d] that both Christmas and

\footnotetext{
270. Lynch, 465 U.S. at 672.

271. Id. at 674-82.

272. Id. at 681-82.

273. Id. at 693 (O'Connor, J., concurring).

274. Id. at 716 (Brennan, J., dissenting).

275. 492 U.S. 573 (1989).

276. Id. at 578-79.

277. Id.

278. Id. at $614,618-20$.
} 
Chanukah are part of the same winter-holiday season, which has attained secular status in our society."279

Justice O'Connor, concurring, also concluded that the inenorah display was constitutional. ${ }^{280}$ But she criticized Justice Blackmnn's claim that the menorah was a secular symbol. ${ }^{281}$ O'Connor found the displays permissible because the inenorah accompanied by a tree and a sign saluting liberty "did not endorse Judaism or religion in general, but rather conveyed a message of pluratism and freedoin of behef during the hohday season." 282

The rationales in Lynch and Allegheny are unpersuasive. Both the Court and O'Connor claimed that the nativity display did not endorse or advance religion. But the crèche and the menorah each einbody a particular set of theological religious beliefs-not merely tenets of the civil rehgion sliared by Americans of different faiths and no faitl at all. It is liard to understand low the addition of nonreligious syinbols can totally strip these symbols of their religious significance. ${ }^{283}$

The Court and Justice $O^{\prime}$ Counor, then, failed to slow that the symbols in Lynch and Allegheny were similar to the rituals in Marsh and Weisman. In fact, the syinbols in the former two cases are unlike the rituals in the latter cases. Because the religious symbols in Lynch and Allegheny were specifically theological, they sliould be subject to Establishment Clause scrutiny in a way that the civil religious symbolism in Marsh and Weisman slould not.

Ceremonial deisin, then, is a nebulous and ill-defined concept that has beconie nothing inore than a sliortliand for wliat soine Justices believe are "constitutionally acceptable religious practices." Cerenionial deisn is inadequate because it carmot distinguish between the type of patriotic civil religious prayer involved in Weisman and theologically religious symbols in Lynch and Allegheny. Civil religion is a far better concept because it is clearly defined, subject to scholarly study, and capable of inaking distnictions between sectariamisnı and widely held civic beliefs.

\section{Other Thorny Issues}

The civil religion framework will also lielp resolve other thorny issues that arise in Establishment Clause hypotheticals. Civil religion can

279. Id. at 616.

280. Id. at 632 (O'Connor, J., concurring).

281. Id. at 633 .

282. Id. at 635 .

283. Furthermore, even if the addition of nonreligious symbols did strip the religious symbols of their religious significance, it is hard to understand how a Court could accurately identify the point at which this stripping occurs. Lynch and Allegheny suggest that this identification process would amount to little more than a guessing game about how many Easter bunnies it takes before the display of a cross becomes constitutional. 
provide a way to justify longstanding cultural practices that, under some strict readings of Lemon, might be found unconstitutional. For example, inaugural prayers, the invocation used each time the Supreme Court itself hears argument ("God save this honorable Court"), Thanksgiving and National Day of Prayer proclamations, the words "under God" in the pledge of allegiance, the phrase "In God We Trust" on coims, and even the ritual Presidential benediction "God Bless America" can all be better justified with reference to the concept of civil rehigion mstead of ceremomal deism.

Under the Supreme Court's current approach to the Establishment Clause, the argument in favor of these practices usually takes one of two forms. The first is that such practices have the secular purpose of solemnizing the occasion in question. The second is that such practices have lost, over the years, any rehigious significance that they once may have had. But these arguments iguore the important role such practices play in reinforcing our national self-conception. These practices continue, in large ineasure, precisely because they continue to have substantive significance that extends beyond mere solemnization. Because these practices involve only civil rehion, they are necessarily permissible under the Estabhishment Clause.

\section{B. Financial Support for Religion}

Many of the inost difficult Estabhshment Clause cases involve not pubhc acknowledgments of civil religion, but rather government financial support for rehgion. Unlike acknowledgment of rehgion, support involves government financial assistance to theological rehgious organizations. Direct governmental assistance to parochial schools, tax exemptions for churches, and state vouchers for private schools are examples of such financial support. Although this kind of support inevitably involves interaction between the state as state and a church as an institution, the sociological analysis presented liere suggests that government attempts to support religion ought to be viewed favorably, since the expanding state and market are inaking it increasingly difficult for religion to fulfill its traditional character-forming functions.

The distinction between tlieologically religious activities and civil religious activities provides the foundation for the new test needed in this area. Such a test should focus on whether the aid to a theologically religious group supports its theological or character-forming activities. Aid to theological activities poses a threat to religious liberty and should be closely scrutinized. Aid to civil society activities, however, supports values that are critical to the survival of democracy and should be permitted.

The evaluation of any program must be made with the three-sector inodel's primary values in mind. First, the democratic values that reli- 
gion promotes should be encouraged. The government has an interest in promoting the values that rehigion cultivates. Personal responsibility, community awareness, and inutual care, among other values, are all essential to the survival of democratic government. Second, religion's autonomy inust be preserved.

In order to support these values, the government inust be able to support rehigion's civil society activities but must not be allowed to aid theologically religious activities. In a school setting, this means that it should be permissible for the government to directly fund private rehgious schools, except for that portion of their budget for curricular and extracurricular activities devoted to teaching theological belief.

For example, imagine a typical Catholic higli school in the suburbs of City $A$. This school resembles its public school counterparts in most ways. Both schools will offer the number of science, math, English, history, language, and physical education courses required by the state. Both will also offer elective courses, ranging from advanced academic courses to art classes and mechamical or "shop" training. The Catholic school will differ, however, froin its public counterpart in at least one major way: a portion of its curricular day (usually one period) and its extracurricular activities (usually student retreats and occasional masses) will be devoted to specifically religious activity.

The insights of the three-sector inodel urge that government be allowed to fund the nontleologically rehigions portion of the curriculuni. These activities promote values even where no theologically rehigious beliefs are embraced, while the theologically religious activities inake embracing a theological belief a necessary condition for realizing the other, civil society values. The budgeting process for these schools would be a simple one. The school's budget would have two categories: a "civil society" category, which could be funded by the state, and a "theologically religious" category, which would include the salaries of rehigion teachers, the cost of rehigion books, and expenses for students' theologically religious activities. The civil society category could permissibly be funded by the state.

There is no persuasive reason why the government should not be allowed to fund the civil rehigious aspects of religious private schools. It cannot be the specific types of activities to which objection is raised, smce the government already funds precisely those activities in the public schools. Instead, the objection must be that theologically religious activities permeate the entire school curriculum, and that the government will actually be advancing that theological belief and not merely promoting general, civil societal values. ${ }^{284}$

But this objection is not convincing. It is undoubtedly true that

284. See Choper, supra note 172, at 29495 . 
some religious groups view some of their character activities as a way to promote theologically religious belief. The fact that religious groups conceive of them that way, however, does not cliange the reality that these activities liave benefits that do not necessarily depend on whether the beneficiaries embrace any theologically religious belief. Any incidental benefit to theologically religious belief from religion's civil society activities seems insufficient to override the primary benefits to society froin the critical role these activities play in promoting democratic values.

For example, imagine a very humorous, cliarisınatic, understanding nun who teaches calculus and a scliolarly, kind, insightful priest who teaclies English. The students in these classes may be influenced by these teachers, but it is not the same kind of influence that the nun or priest would have teaching Catlolic doctrine. In calculus, the nun teaclies the truth of limits, not the limits of truth; im English, the class studies Shakespeare, not the Book of Revelation. While the school is rooted in the liope that students will experience the kindness, generosity, intelligence, and caring of these teachers and seek to emulate tlose qualities, this emulation is not a prerequisite that students must fulfill to receive the other educational and civil society benefits, such as a better understanding of matll and English and a better appreciation of the virtue of kindness and generosity. Indeed, keeping these civil society values from being taught undermines collective identity and slowly tears the fabric that holds society together.

The activities by religious institutions that should be supported are essentially community-building activities. Funding benefits religion, but only to the extent that religion creates the type of communities that foster the values essential for democracy. ${ }^{285}$ The civil society/theologically religious distinction does not permit funding for solely theological activities, where the benefit depends on whether a theolgically religious belief is advanced. ${ }^{286}$ This distinction botl accurately reflects the insiglits of the three-sector model and protects religious liberty. Religion should be funded to the extent it promotes values crucial to democratic government.

But, to the extent that religious activities are solely theological in nature, they should not be funded by the government. One example of such an activity is a released-time program, which allows public scliool students the option to study religion during the scliool day in classes

285. See supra note 171.

286. Cf. Choper, supra note 172, at 278. Andrew M. Greeley argues that the Catholic "sacramental imagination," which sees the world and human relationships as fundamentally good and filled with God, leads most Catholics to "stress those values and behaviors that contribute to the building up and strengthening of [sociall networks." GREELEY, supra note 8, at 47, 34-64. Even if Greeley is right, lowever, the societal benefits from this sacramental understanding are still derivative, not independent, of the belief. 
taught by privately employed rehion teachers. In Zorach v. Clauson, ${ }^{287}$ the Court upheld these programs when the rehigious classes were held in church buildings. On the other hand, in McCollum v. Board of Education, ${ }^{288}$ the Court prohibited these programs when the rehious classes were held on public school property.

The sociological analysis presented here would not automatically allow either type of program, and would not distinguish between thein. Such released-time programs are specifically designed to aid rehion im its teaching of theological behief. These classes are essentially catechism conducted on school time. They are theologically religious in nature, and therefore should be subject to Estabhishinent Clause scrutiny.

\section{VII \\ CONCLUSION}

Rehigion and politics are areas of public life in the Umited States that evoke passion, behef, ideals, and conflict. It is treinendously important that the Court 1nomitor their delicate relationship through its Estabhishment Clause jurisprudence. The Court should act with awareness of the role religion actually plays in American society rather than out of a philosophical predisposition for or against religion.

The sociology of rehigion reveals two concepts tliat can greatly improve the Court's Establishment Clause jurisprudence. First, civil religion is conceptually mucli clearer than the nebulous notion of "cereinomal deisin" currently used by the Court in the public acknowledgment cases. It allows the Court to identify the ways in which public acknowledgments of religion are an integral part of national history and identity.

Second, the three-sector inodel provides the foundation for a new approach which will enable the Court to appreciate the values at issue in the support-for-rehion cases. It enables the Court to balance society's need for a liealthy imstitutional religion witlı individual freedoin and to understand the challenges that bureaucratization, technology, and clianges within rehgion itself pose for future Estabhishinent Clause disputes. 
